\title{
Environmental indicators combined with risk analysis to evaluate potential wildfire incidence on the Dadu Plateau in Taiwan
}

Chao-Yuan Lin ( $\nabla$ yuanlin@dragon.nchu.edu.tw)

National Chung Hsing University https://orcid.org/0000-0003-0577-3662

Pei-Ying Shieh

National Chung Hsing University

Shao-Wei Wu

National Chung Hsing University

Po-Cheng Wang

National Chung Hsing University

Yung-Chau Chen

National Chung Hsing University

\section{Research Article}

Keywords: Remote Sensing, Principal Component Analysis, Fire Hazard, Fire Vulnerability, Normalized Burn Ratio

Posted Date: November 19th, 2021

DOI: https://doi.org/10.21203/rs.3.rs-1080863/v1

License: (9) (1) This work is licensed under a Creative Commons Attribution 4.0 International License. Read Full License

Version of Record: A version of this preprint was published at Natural Hazards on March 19th, 2022. See the published version at https://doi.org/10.1007/s11069-022-05300-3. 


\section{Environmental indicators combined with risk analysis to evaluate potential wildfire incidence on the Dadu Plateau in Taiwan}

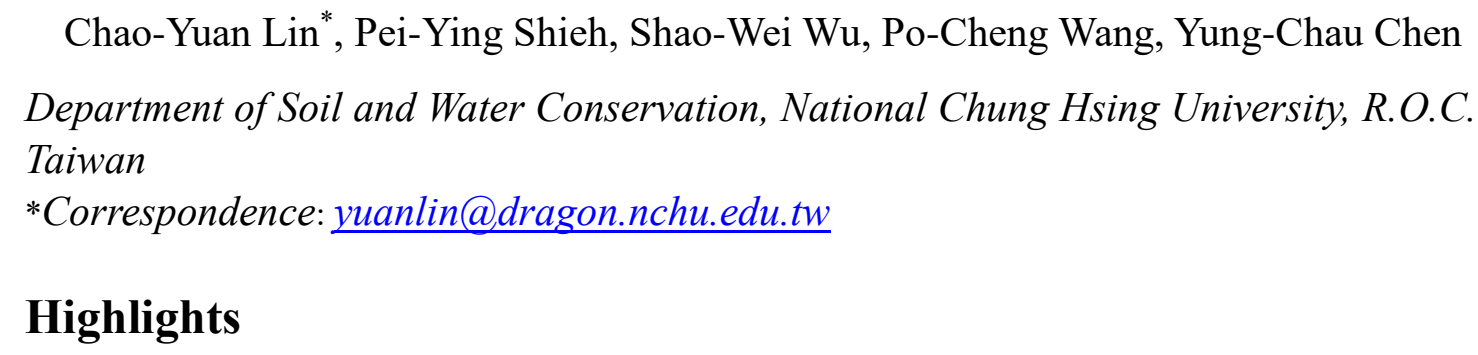

\section{Highlights}

- Establish a Spatio-temporal distribution of wildfire risk model by combining remote sensing images, meteorological observations and field surveys of environmental indicators at different scales.

- Assess the impact of atmospheric humidity changes on the initial threshold of $d N B R$.

- Village-based fire risk models related to fire control operations can be applied to periodic wildfire areas.

\section{ABSTRACT}

Wildfire is a common disaster in the world, and it has a considerable impact on the safety of residents and ecological disturbance. Periodic wildfires are an urgent problem to be solved. This research uses big data from relevant departments to extract environmental indicators that affect wildfires, including satellite images, meteorological observations, and field surveys and establishes a risk model for the Spatio-temporal distribution of wildfires based on risk analysis. Previous studies using Differenced Normalized Burn Ratio $(d N B R)$ to assess fire severity and distinguish wildfire ruins did not deal with the impact of atmospheric humidity on $d N B R$ values. In this study, an adjustable fire threshold was developed to enable $d N B R$ to improve the accuracy of identifying wildfire locations. Regarding the temporal distribution of wildfire risks, environmental vulnerability cannot specifically reflect the frequency of actual wildfires. If the hazard degree is introduced to calculate the wildfire risk, the coefficient of determination can be increased from 0.49 to 0.79 . The verification of the village boundary zone depicts that the risk analysis can effectively show the temporal and spatial distribution of wildfire hotspots. On this basis, a village-level wildfire disaster prevention strategy can be formulated. 


\section{Introduction}

Global wildfire research mainly focuses on forests, tropical forests and grasslands in North America and Northern Eurasia, Mediterranean climate zones in Europe and Australia, and Southeast Asian monsoon regions (Bowman et al. 2009; Ying et al. 2021). Taiwan is located in the East Asian monsoon region, and it is also a place where wildfires occur frequently. In addition to being affected by climate, changes in land use caused by human activities (Chiu et al. 2012) are another key factor causing frequent wildfires. Over the past decade, the average seasonal length of wildfires has increased by $18 \%$ due to climate impacts (Jolly et al. 2015), leading to an increase in the frequency and severity of wildfires, a trend that has worsened with the increase in man-made development. With infrastructure construction and rapid economic development, special attention has been paid to the control and management of potential wildfire risks in the region, especially in hillside areas. Wildfires will burn vegetation, expose the soil, change the physiochemical properties of the soil, and accelerate erosion and degradation (Moody et al., 2013; Shakesby and Doerr, 2006). Furthermore, wildfire could contribute to the formation of water-repellent layers on the surface (Bowker et al., 2004; Ravi et al., 2009; Shakesby and Doerr, 2006). This phenomenon, in addition to reducing soil infiltration, also increases surface runoff (Neary and Gottfried, 2002; Pausas et al., 2008) and peak flow (Costa 1987; Hasan et al. 2020), which reduce water storage capacity and can easily lead to flooding in downstream urban areas of Dadu Plateau during heavy rains (Cho 2017). Slope stability of burned site can also lead to forest degradation and collapse (Benda and Dunne, 1997; Jackson and Roering, 2009), posing a major threat to downstream urban infrastructure and livelihoods. Wildfire is an important factor that interferes with the ecosystem, and fire intensity and frequency affect the structure/function of the ecosystem (Sankey et al., 2013; Westerling et al., 2006). Frequent wildfires reduce forest area and hinder plant succession. Ecologically, migratory birds may also be affected by reduced species abundance and forest ecological habitat loss (Tsai 2005). In addition, fires release carbon and increase the burden of global greenhouse gases, leading to intensified global warming. Extreme weather makes wildfires more frequent and destructive (Westerling et al. 2006; Turco et al. 2018).

An average of 57 wildfires occurs in Taiwan's forests each year, which is the 
most frequent area of Taiwan's wildfires. In comparison, there are more than 400 in Dadu Plateau (Chuang 2015). This is related to the land development dominated by local human activities and plant characteristics. The forest form of Dadu Plateau is dominated by Taiwan acacia (Acacia confusa Merr.), and the grassland is mainly distributed by Guinea grass (Panicum maximum Jacq.) (Lin and Yang, 2001; Tsai, 2005). Many studies have shown that wildfires are associated with meteorological factors such as rainfall (Hsiao 2003), relative humidity (Lai 2003; Lin et al. 2005), temperature (Hsiao 2003; Chiu et al. 2004), and wind speed (Chiu et al. 2004). The growth of Guinea grass in the Dadu Plateau will quickly wither and become a source of fire, which will burn easily after October due to plummeted rainfall and the effects (the formation of burning wind on the leeward side) of the northeast monsoon (Chuang, 2015; Lin and Yang, 2001; Tsai, 2005). In addition, most fires are caused by farming and animal husbandry, as well as the common sacrificial customs in traditional Chinese festivals, such as burning paper and burning incense (Lin et al. 2008; Chuang 2015).

Wildfire is a coupled phenomenon, involving multiple factors, such as environmental humidity conditions, fuel flammability (fuel moisture content), natural and man-made ignitions, weather and other comprehensive factors (Gudmundsson et al., 2014; Pyne and Andrews, 1984). The important information of wildfires can be extracted through satellite remote sensing data. It has the characteristics of real-time and large area and has been widely used in fire modeling at different scales around the world (Tian et al. 2013; Abatzoglou et al. 2018; Chen et al. 2020). Therefore, understanding the changes in land cover, environmental climate conditions and past historical fire data will help wildfire risk modeling and wildfire management and prevention. Due to the many factors involved, most wildfire models are built under the risk concept framework, using machine learning and artificial intelligence statistical methods to aggregate complex variables into a comprehensive index (Oliveira et al., 2021). However, there are still research gaps in the spatial and temporal distribution of potential wildfires. This study used Guinea grass samples and satellite imagery, meteorology and land-use data to detect changes in biomass and tissue moisture content on a monthly basis to determine the associated indicators affecting the occurrence of wildfires. Finally, a wildfire risk model at the village level was established for reference by local fire stations and residents for wildfire control. 


\section{Materials and methods}

103

104

105

106

107

108

109

110

111

112

113

114

115

116

117

118

119

120

121

122

\subsection{Study Area}

Dadu Plateau is located in central Taiwan $\left(120^{\circ} 30^{\prime} \mathrm{E}-120^{\circ} 40^{\prime} \mathrm{E}, 24^{\circ} 20^{\prime} \mathrm{N}\right.$ $\left.-24^{\circ} 05^{\prime} \mathrm{N}\right)$. The altitude of the Plateau is about $200 \sim 300 \mathrm{~m}$ (Fig. 1-left). The terrain is uplifted by the thrust of the fault, forming a terraced terrain with steep west and gentle east. Weather and climate are mainly affected by the East Asian monsoon belt. Based on the data of the Wuchi Meteorological Station, the average annual temperature is about $23^{\circ} \mathrm{C}$, the coldest monthly mean temperature is $15.9^{\circ} \mathrm{C}$, and the hottest monthly average temperature is $29.2^{\circ} \mathrm{C}$ (Central weather bureau, 2006 to 2015). The average monthly rainfall is about $47.5 \mathrm{~mm}$ and $182.5 \mathrm{~mm}$ for the dry duration (October to the following April) and wet duration (May to September) respectively. The land use is mainly forest, grassland, agricultural land and building (Fig. 1-right), which is affected by the local soil properties. The soil is laterite with the properties of acidity, lack of organic matter, high viscosity/plasticity and well drained, and is not suitable for cultivation due to low productivity and lack of irrigation facilities (Chiu et al. 2012). The grassland is dominated by Guinea grass, which is a fire-adaptive species with tiller ability and can survive well on acidic and barren soils (Lin 2000). Taiwan acacia with symbiotic rhizobia in its root systems (Lee 2013) is the main woody plant at the afforestation areas. According to fire reports, $83 \%$ of the fire ruins can be found on the grasslands, and the clear ecotones formed by wildfires are usually spotted at the adjacent grassland.
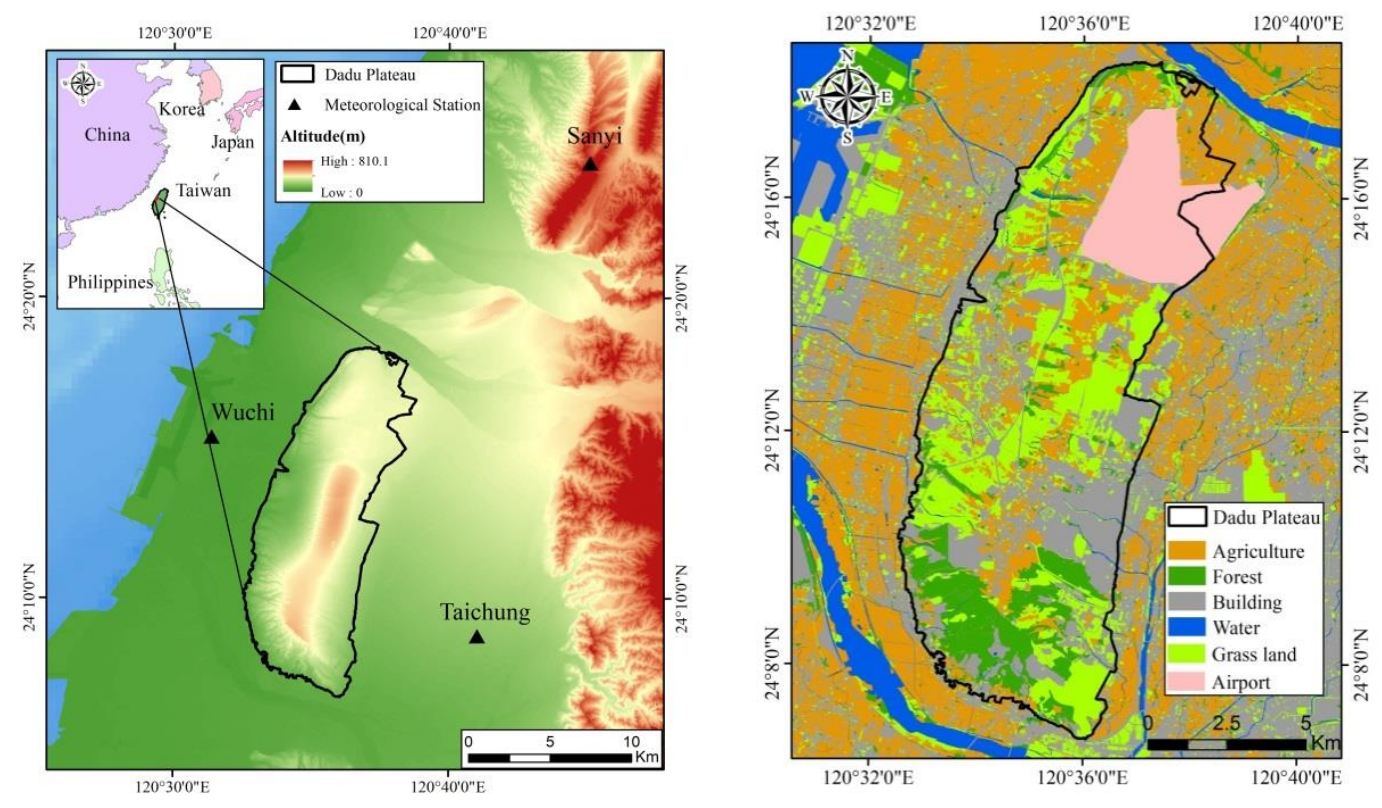
Fig. 1 The location and elevation distribution of Dadu Plateau (left) and land use type (right) extracted from DEM and map data of the National Land Surveying and Mapping Center (https://maps.nlsc.gov.tw/).

\subsection{Study materials}

The spatial and temporal distribution of wildfire risk was analyzed using data from 2006 to 2015. Meteorological data is extracted from the annual weather report of the central weather bureau (https://e-service.cwb.gov.tw/HistoryDataQuery/) to calculate the monthly Evenoff's moisture coefficient (EMC) and average wind speed.

129 Satellite images Landsat 4-5 TM and Landsat 8 OLI/TIRS are derived from the center

130 of the US Geological Survey website (http://earthexplorer.USGS.gov/) to extract 131 relevant environmental indices that affect the occurrence of wildfires. In addition, 132 biomass and tissue moisture content are derived from the monthly data of the on-site 133 survey from 2014-2015, and fire case provided by the Fire bureau is used for model 134 validation.

\section{3. Methods}

3.1 Wildfire model based on risk concept

Wildfire risk is often a combination of potential environmental vulnerability factors and external hazard disturbances, such as persistent drought, excessive accumulation of flammable fuels, environmental humidity, man-made activity and development. In the theory of natural disaster risk assessment, wildfire risk assessment is widely and prominent. The Intergovernmental Panel on Climate Change, IPCC risk analysis model (IPCC, 2014) was used to define wildfire risk based on the product of wildfire hazard and environmental vulnerability as follows:

$$
\text { Risk }=\text { Hazard } \mathrm{x} \text { Vulnerability }
$$

The risk is the probability of wildfire occurrence, the hazard is the probability of 146 ignition, and vulnerability is the flammability of fuels. In this study, the risk of

147 wildfires will be discussed based on temporal and spatial distribution and extracted 148 the relevant environmental indicators according to the vulnerability and hazard. The 149 establishment of the temporal wildfire risk model is to evaluate the wildfire risk of 150 each month on a monthly basis; the spatial wildfire risk model aims to draw a wildfire 151 risk map of the Dadu Plateau during the period of high wildfire risk. 
153

154

155

156

157

158

159

160

161

162

163

164

165

166

167

168

169

170

171

172

173

174

175

176

177

178

179

180

181

182

\subsubsection{Wildfire vulnerability indicators}

The research first takes environmental factors from weather data, remote sensing data, and field surveys as environmental vulnerability, uses principal component analysis (PCA) to combine various environmental vulnerability factors into a comprehensive index, and uses monthly wildfire vulnerability to assess wildfire risk. EMC is one of the drought indices based on cumulative rainfall, temperature, and relative humidity and can be considered a composite index of atmospheric moisture content ( $\mathrm{Li}, 1990$; Yen and $\mathrm{Wu}, 2004)$. Based on accumulated rainfall, average temperature and mean relative humidity at nearby weather stations (Wuchi, Taichung, Sanyi) from 2006 to 2015 (Fig. 1-left), EMC of each station is calculated using monthly data, and then uses Thiessen's polygon approach to interpolate the research site's EMC. Thiessen's polygon approach is a common method of estimating meteorological factors in sample areas using weather stations, which calculate the weight of weather factors based on their control areas to understand EMC's monthly change. The EMC formula can be represented as follows:

$$
\mathrm{EMC}=\frac{R}{E_{0}} \quad E_{0}=0.0018(25+T)^{2}(100-r)
$$

$T$ is the average temperature $\left({ }^{\circ} \mathrm{C}\right) ; r$ is the mean relative humidity $(\%) ; R$ is accumulated rainfall $(\mathrm{mm})$. Monthly mean wind speed of the site is also estimated from the stations by Thiessen's polygon method.

Vegetation such as forests, grasslands and farmland in the Dadu Plateau can be considered the main fuel for wildfires. Normalized Difference Vegetation Index can be extracted from the red and near-infrared light of satellite images (Rouse et al. 1973). In order to facilitate large-scale vegetation monitoring, the monthly NDVI is used to understand the trend of NDVI changes. NDVI changes are mainly influenced by environmental stresses such as soil moisture content, nutrient supply, tissue disease, and farming behavior (Fiorucci and Gaetani, 2007). Over the years, many authors have proposed using NDVI changes to assess the likelihood of wildfires in vegetation (Lasaponara 2005) and using NDVI as an index of wildfire vulnerability (Fiorucci and Gaetani, 2007).

Moisture content of plant tissue is a key factor affecting wildfire occurrence and development. Normalized Difference Water Index (NDWI) is defined as the 
183 reflectance difference of near-infrared $(N I R)$ and shortwave-infrared light ( SWIR)

184 divided by the sum of the two, the more moisture content in the plant tissue the less 185 probability of ignition, and could be applied to reflect the variations of plant's 186 moisture content. NDWI has a higher sensitivity compared to NDVI for vegetation 187 moisture content (Karamihalaki et al. 2016).

188 According to fire report statistics, wildfires mainly occur in the dry season and 189 usually occur in grasslands. This may be due to the rapid withering and fuel 190 accumulation during the dry season. Guinea grass has become a major fire-adapting 191 species on the local grasslands under long-term periodic wildfires. In addition to using 192 the overall NDVI and NDWI as environmental vulnerability factors, monthly changes 193 of biomass and/or moisture content of the Guinea tissue were investigated to be as 194 factors of fire vulnerability. According to the plant quantitative survey (Lin 2013); 195 random plots $(1 \mathrm{~m} \times 1 \mathrm{~m}$, three replications) of grassland located at the western 196 Cheng-kung-ling were selected for regular monthly sampling from 2014 to 2015. The 197 biomass and/or moisture content were calculated according to the manual of herbal 198 treatment (Shyu et al. 2003). The Guinea grass of the sample plot was cut off to 199 measure its fresh weight on an electronic scale, and dried in the oven for 48 hours at 20085 degrees Celsius, and the resulting dry weight was biomass. The moisture content 201 percentage is (fresh weight - dry weight)/dry weight $\times 100 \%$. Finally, the monthly 202 NDVI, NDWI, biomass and moisture content are used as wildfire vulnerability 203 indicators.

\subsubsection{Statistical analysis}

205 Environmental vulnerability consists of a variety of index variables, which are 206 difficult to explain due to the complexity of the data. Therefore, PCA is used to reduce 207 the dimensionality of seven environmental vulnerability variables. PCA is a common 208 machine learning method widely used to process big data today (Holland, 2019; 209 Jolliffe and Cadima, 2016). By transforming a large set of variables into a smaller set 210 of variables, which still contains most of the information in the large set, the principal 211 components with eigenvalue greater than 1 are selected to calculate the 212 comprehensive vulnerability index for wildfire occurrence.

213 Before PCA, the value range of each factor must be standardized to obtain its 214 influence weight. Due to the positive and negative relationship between impact factors 215 and fire occurrence, biomass, NDVI and wind speed factors that have a positive 
contribution to fire vulnerability can be standardized as normalized biomass (nBM), normalized NDVI (nNDVI), and normalized Wind speed (nWS) is expressed by the following equation.

$$
y=\frac{x_{i}-x_{\min }}{x_{\max }-x_{\min }}
$$

Where $y$ is the standardized value, $x_{i}$ is the original value of index $i$, and $x_{\max }$ and $x_{\min }$ are the maximum and minimum values of the index, respectively.

Factors that have a negative impact on fire vulnerability, such as EMC, NDWI, and moisture content, can be inverted into iEMC, iNDWI, and iMC; then normalized to niEMC, niNDWI, and niMC through the above equation.

\subsection{Spatial distribution of wildfire risk}

Select the time period most prone to wildfires, and use the environmental indicators of wildfire vulnerability and hazards to draw a wildfire risk spatial distribution map.

\subsubsection{Spatial distribution of wildfire vulnerability}

Wildfire vulnerability represents the ability of the environment to resist fire that may occur from external forces. Areas with high wildfire vulnerability are easy to ignite and burn after contact with a fire source. Among the factors that affect the temporal distribution of wildfire vulnerability, only NDVI and NDWI extracted from satellite images are used to map the spatial distribution in a specific time interval environment. Due to insufficient spatial resolution of meteorological data, and NDVI and NDWI already reflect the information of biomass and tissue moisture content, such temporal distribution modeling variables are excluded from spatial distribution modeling. Generally speaking, areas with vigorous vegetation growth have greater potential for fuel accumulation, which can promote combustion or the spread of wildfires; fuel moisture also affects the burning rate. Therefore, NDVI and NDWI are used to express fuel quantity and moisture index respectively.

Fuel properties also affect the occurrence of wildfires, so the type of land cover is closely related to the fire event. Brown and Davis (1973) pointed out that grass is a kind of light fuel, which is characterized by the rapid loss of water from plant tissues and air supply flux, making it easy to catch fire and spread, but burning does not usually last for a long time. However, the heavy fuel of wood is not easy to burn because the tissue moisture is not easy to lose, but after being ignited, it burns more 
and lasts longer.

Landsat images are classified according to maximum likelihood classification 249 (Lillesand et al. 2000) and supervised classification. The images provided by Google 250 Earth are used for ground truth training. Google Earth satellite images are mainly 251 high-resolution images of the DigitalGlobe series of satellites, which can be used to 252 interpret the spectral statistical data of each training sample as a basis for image data 253 classification. After using supervised classification for image classification, ground 254 truth data needs to be compared with each other to determine whether the 255 classification result is accurate and whether it meets the requirements. Accuracy 256 evaluation uses classification results to compare ground truth data, calculates the 257 number of random samples using the formula proposed by Yamane in 1967, and uses 258 the overall accuracy of the error matrix and Kappa coefficient as the accuracy 259 evaluation criteria.

260 The dry season images most prone to wildfires are used to describe land use in 261 agriculture, grassland, forest, and bare land. The vegetation types of agriculture and 262 grassland are easy to burn and can be classified as light fuels. Forests can be classified 263 as heavy fuel, and bare land is classified as non-fuel. Standardized fuel characteristic 264 values can be divided into three levels $(1,0.5,0)$, and the spatial distribution of fuel 265 properties can be distributed according to the type of land cover.

2663.4 Temporal/ Spatial distribution of wildfire hazard

267 Hazard can be defined as the degree to which external forces affect natural 268 disasters. Lightning and human activities may be the cause of wildfires, but they are 269 difficult to observe and quantify. Under periodic wildfire conditions, the burning 270 frequency of a place can be considered as one of the fire hazard indexes. Historic 271 wildfire sites can be considered as fire spots and are most likely to catch fire in the 272 future. Therefore, the extraction of wildfire locations in the past is a fire hazard index 273 for assessing the fire risk of a specific location.

$274 \quad$ Normalized Burn Ratio (NBR) proposed by Caselles and López García in 1991 275 was applied to extract the burned sites from satellite images. The near infrared (NIR) 276 with a wavelength of $0.76-0.90 \mu \mathrm{m}$ and the short-wave infrared $\left(S W I R_{2}\right)$ with a 277 wavelength of $2.08-2.35 \mu \mathrm{m}$ in the Landsat satellite sensor are used to describe 278 possible burning locations. The value of $N B R$ ranges from -1 to 1 . The higher the 279 value, the denser the vegetation. Conversely, the lower the value, the sparser the 
vegetation coverage. $N B R$ can be expressed as:

$$
N B R=\frac{N I R-S W I R_{2}}{N I R+S W I R_{2}}
$$

In order to avoid misjudging areas with low $N B R$ values as burning locations, (Key and Benson (2005) proposed $d N B R$ to quantify environmental changes in fire disturbances. $d N B R$ can be expressed as:

$$
d N B R=N B R_{\text {prefire }}-N B R_{\text {postfire }}
$$

By subtracting two $N B R$ images, the changes in grid $d N B R$ values in the images before and after the fire can be understood to reflect the severity of the combustion. Key and Benson (2005) used $d N B R$ values in conjunction with wildfire ground surveys to propose fire severity classifications (Table 1). These thresholds are usually used to determine the severity of combustion and effectively extract the location of combustion (Epting et al. 2005; Hall et al. 2008; Soverel et al. 2011).

Table 1 Classification of burn severity

\begin{tabular}{cc}
\hline Burn severity & $d N B R$ \\
\hline unburned & $-0.100 \sim 0.099$ \\
low & $0.100 \sim 0.269$ \\
low-medium & $0.270 \sim 0.439$ \\
medium-high & $0.440 \sim 0.659$ \\
high & $0.660 \sim 1.300$ \\
\hline
\end{tabular}

Key and Benson (2005)

However, when using fire severity to classify the fire range, it should be noted that the initial threshold of $d N B R$ is not a fixed value. Since the initial threshold of $d N B R$ is affected by atmospheric humidity, if a fixed initial threshold of $d N B R$ is used to extract the fire range, the image must be limited to the same period (Fang and Yang, 2014). In order to effectively and automatically use $d N B R$ to identify the fire scene, it is necessary to consider the influence of atmospheric humidity changes on the telemetry images taken in the two stages. In this study, the real fire scene image was used as the basic image, and the $d N B R$ was adjusted to the boundary of the fire site based on the pseudo-color image (Fig. 2-left) to obtain the initial threshold of the $d N B R$ (Fig. 2-right). In addition, we use the difference (Overall $d N B R$ ) of the average 
$N B R$ of all grids of the two images in the study area as an indicator of the influence of 305 changes in atmospheric humidity during the two periods. Use the initial threshold of $d N B R$ obtained from each wildfire event as the y variable and the overall $d N B R$ as the $\mathrm{x}$ variable to find the correlation between the two variables. Then the initial threshold of $d N B R$ can be dynamically evaluated through regression analysis.
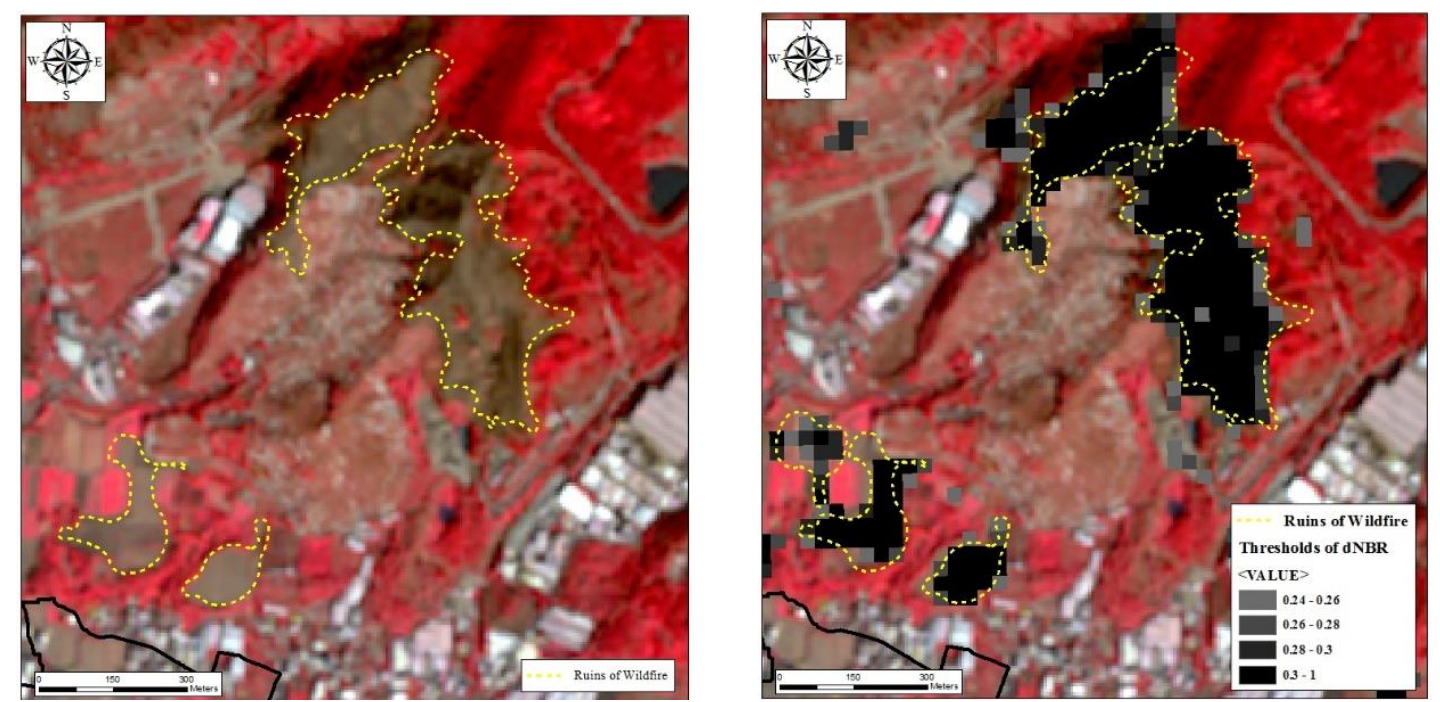

Fig. 2 Fire ruins explained from false color images based on Landsat image data (left). Fire remains extracted from different initial thresholds of $d N B R$ (right).

Based on the characteristics of $d N B R$, this research studies the hazards of spatio-temporal distribution in risk assessment. The temporal distribution is based on

315 the total area of fire sites in each period, and the spatial distribution analysis includes 316 not only the frequency of fires in each region during a fixed period, but also the 317 severity of wildfires.

\subsubsection{Wildfire Risk Model Verification}

319 (1) Burned sites extraction

320 The changes in NDVI before and after wildfires were used to extract burned 321 locations. Using K-means analysis to define high and low NDVI from the images 322 before and after the fire, then the vegetation changes can be divided into four 323 categories to identify the burning location. Therefore, the NDVI change level remains 324 the same or higher, and is classified as a non-fire area, and the NDVI change belongs 325 to a lower category, which can be regarded as a burning site that can be used to verify 326 wildfire risk models.

327 (2) Verification of village units 
Spatial wildfire risk modeling is based on the grid scale of the image as the analysis unit. Once a wildfire occurs, it will spread rapidly and will not stop until there is not enough fuel to burn, so it is easy to break through the grid unit. Firebreak can effectively reduce and control the spread of fire (Ascoli et al. 2018; Fernández et al. 2019). Firebreaks comprise both natural and artificial barriers. Common natural barriers include cliffs, streams, valleys and ridge lines (Whitman et al. 2018). Artificial fire belts include green firebreaks (Cui et al. 2019) and roads (Laschi et al. 2019). Therefore, it is more appropriate to introduce fire belts as a concept for spatial wildfire risk assessment and verification. This study uses the village boundary as the division unit. The criteria for dividing villages are based on 1. Valley or ridgeline. 2.

338 The center line of roads, alleys and river ditch. 3. Permanent gates, ponds, bridges and 339 buildings that can be used as boundaries, all have the function of fire protection belts. 340 A total of 62 villages (including airports) on the Dadu Plateau were used as the 341 verification basis for the spatial wildfire risk assessment. Through the modeling 342 results of the village districts, it can be more visually applied in fire management.

\section{Results}

$344 \quad 4.1$ Temporal distribution of wildfire vulnerability

\subsubsection{EMC and mean wind speed}

According to the statistical analysis of meteorological data from 2006 to 2015, the highest average temperature occurred in July $\left(29.17^{\circ} \mathrm{C}\right)$ and the lowest occurred in January $\left(16.13^{\circ} \mathrm{C}\right)$; the lowest average relative humidity $(72.8 \%)$ occurred in October and the highest $(81 \%)$ occurs in February; there is relatively high precipitation in June to August and relatively low rainfall during October to February. The EMC of each month could be obtained from the calculation of the above three meteorological factors and shows relatively high value during May to August. A high EMC value implies greater moisture content in the air. The mean wind speed for each month is

355 The monthly normalized linear reversed EMC (niEMC) and the normalized wind 356 speed (nWS) are listed in Table 2.

\subsubsection{NDWI and NDVI}

358 Satellite images are used to extract monthly averages of NDVI and NDWI (Table 359 2). Fig. 3 shows a significant increase in nNDWI and nNDVI from April to May due to 
360 abundant rainfall during the rainy season and adequate water use for plant 361 photosynthesis. At the beginning of the dry season (September to October), nNDWI is 362 on a downward trend due to reduced rainfall, while nNDVI is sluggish. NDWI is more 363 sensitive to changes in atmospheric moisture than NDVI. Overall, the monthly changes 364 in nNDWI and nNDVI are fairly consistent. 
365 Table 2 Meteorological data, EMC, NDWI and NDVI

\begin{tabular}{|c|c|c|c|c|c|c|c|c|c|c|c|c|}
\hline Items & Jan. & Feb. & Mar. & Apr. & May & Jun. & Jul. & Aug. & Sep. & Oct. & Nov. & Dec. \\
\hline Mean Temp. $\left({ }^{\circ} \mathrm{C}\right)$ & 16.13 & 17.10 & 19.10 & 22.82 & 26.06 & 27.95 & 29.17 & 28.89 & 28.05 & 25.24 & 22.12 & 17.83 \\
\hline Mean RH(\%) & 78.74 & 81.03 & 76.49 & 76.83 & 77.29 & 78.31 & 74.99 & 76.70 & 75.36 & 72.84 & 75.25 & 74.07 \\
\hline Accumulated rainfall (mm) & 26.48 & 58.64 & 79.38 & 125.86 & 202.78 & 316.88 & 252.91 & 336.98 & 146.67 & 37.78 & 55.83 & 36.01 \\
\hline EMC & 0.40 & 0.15 & 0.96 & 1.31 & 1.90 & 2.89 & 1.91 & 2.76 & 1.17 & 0.30 & 0.56 & 0.42 \\
\hline niEMC & 0.90 & 1.00 & 0.70 & 0.57 & 0.36 & 0.00 & 0.35 & 0.04 & 0.62 & 0.94 & 0.84 & 0.90 \\
\hline Meam wind speed, $(\mathrm{m} / \mathrm{s})$ & 4.97 & 4.39 & 3.84 & 3.12 & 3.01 & 3.06 & 3.17 & 2.82 & 3.23 & 4.53 & 4.14 & 4.58 \\
\hline nWS & 1.00 & 0.73 & 0.48 & 0.14 & 0.09 & 0.11 & 0.16 & 0.00 & 0.19 & 0.80 & 0.61 & 0.82 \\
\hline NDWI & -0.05 & -0.11 & -0.04 & 0.02 & 0.33 & 0.35 & 0.31 & 0.24 & 0.25 & 0.18 & 0.04 & -0.01 \\
\hline nNDWI & 0.12 & 0.00 & 0.14 & 0.27 & 0.94 & 1.00 & 0.91 & 0.75 & 0.77 & 0.61 & 0.33 & 0.20 \\
\hline niNDWI & 0.88 & 1.00 & 0.86 & 0.73 & 0.06 & 0.00 & 0.09 & 0.25 & 0.23 & 0.39 & 0.67 & 0.80 \\
\hline NDVI & 0.35 & 0.29 & 0.34 & 0.49 & 0.76 & 0.72 & 0.72 & 0.71 & 0.71 & 0.54 & 0.45 & 0.39 \\
\hline nNDVI & 0.13 & 0.00 & 0.11 & 0.42 & 1.00 & 0.92 & 0.92 & 0.91 & 0.91 & 0.54 & 0.34 & 0.21 \\
\hline
\end{tabular}

*The data is derived from the average of the data of each month from 2006 to 2015, and then normalized. 


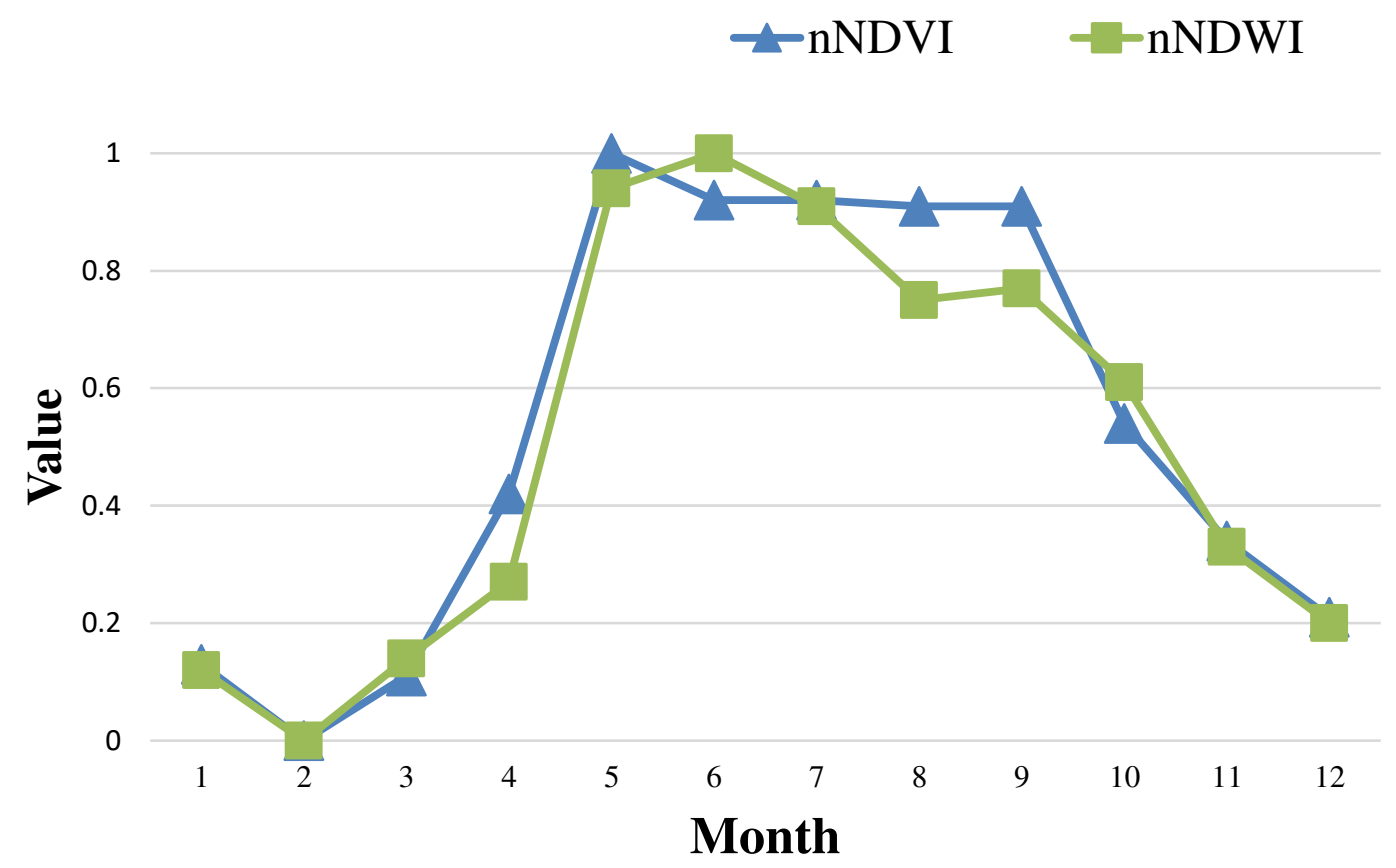

Fig. 3 Monthly changes of nNDVI and nNDWI

4.1.3 Monthly biomass and moisture content of Guinea grassland

Sampling of Guinea grass began in November 2014 and lasted for one year. Unfortunately, the sample sites were destroyed from May to October 2015 due to fire incident. Biomass accumulates with the growth of the plant, and the biomass is supplemented by the accumulation of NDVI throughout the year; NDWI is more sensitive to changes in atmospheric humidity than NDVI, and the moisture content of the plant is supplemented by NDWI. Multiple imputation method was used to supplement the missing data, and regression analysis by statistical software SPSS. The imputation regression equations of biomass and tissue moisture content are as 377 follows:

$$
\begin{gathered}
Y_{1}=1.002+0.068 X_{1}\left(R^{2}=0.88, \mathrm{P}=0.006\right) \\
Y_{2}=56.009+89.089 X_{2}\left(R^{2}=0.60, \mathrm{P}=0.07\right)
\end{gathered}
$$

$Y_{1}$ is biomass, $X_{1}$ is nNDVI accumulation; $Y_{2}$ is moisture content, $X_{2}$ is NDWI. 379 The biomass of grass should increase annually with the growth of grass, but the 380 results show that in the early dry season, the biomass is the highest. During the 381 drought season, plant growth slows down or even decreases slightly due to soil water 382 shortage and feeding by pests or animals. Overall, there is little change in biomass 383 over the year. The results showed no significant difference in the monthly biomass of 
384 the Guinea grasslands, which means that the Guinea grasslands are abundant in fuel

385 all the year round. However, changes in plant moisture content showed a significant

386 difference in the monthly change (Table 3 ).

387

388 Table 3 Monthly biomass and moisture content of the Guinea grassland

\begin{tabular}{ccccccccccccc}
\hline Items & Jan. & Feb. & Mar. & Apr. & May & Jun. & Jul. & Aug. & Sep. & Oct. & Nov. & Dec. \\
\hline $\begin{array}{c}\text { Biomass } \\
\left(\mathrm{kg} / \mathrm{m}^{2}\right)\end{array}$ & 1.04 & 1.07 & 1.04 & 1.08 & $1.15^{*}$ & $1.20^{*}$ & $1.25^{*}$ & $1.30^{*}$ & $1.35^{*}$ & $1.38^{*}$ & 1.53 & 1.34 \\
$\mathrm{nBM}$ & 0.00 & 0.06 & 0.00 & 0.08 & 0.23 & 0.33 & 0.43 & 0.53 & 0.63 & 0.70 & 1.00 & 0.61 \\
$\begin{array}{c}\text { Moisture } \\
\text { content }(\%)\end{array}$ & 53.94 & 48.66 & 46.79 & 55.39 & $85.41^{*}$ & $87.19^{*}$ & $83.63^{*}$ & $77.39^{*}$ & $78.28^{*}$ & $72.05^{*}$ & 64.43 & 53.48 \\
niMC & 0.82 & 0.95 & 1.00 & 0.79 & 0.04 & 0.00 & 0.09 & 0.24 & 0.22 & 0.37 & 0.56 & 0.83 \\
\hline 389 & $*$ & Data imputation based on regression equations of biomass and tissue moisture & & \\
390 & & & & & & & & & &
\end{tabular}

391 4.1.4 Statistical analysis result

392 The principal component analysis was performed using the niEMC, nWS, 393 niNDWI, nNDVI, nBM, and niMC factors described above for variable dimension 394 reduction. After the KMO and Bartlett's Test, there is a medium common factor 395 between the variables $(\mathrm{KMO}>0.7, \mathrm{P}<0.01)$ for principal component analysis. The 396 eigenvalue and variance explained percentages for components 1 and 2 are 4.39, 39773.12 and 1.15, 19.17, respectively (Table 4). Because their eigenvalue is greater than 398 1, two components are retained, and the cumulative variance explained by the two 399 components is $92.29 \%$. This means that the interpretation is good, and most of the 400 original variables can be interpreted.

401

402 Table 4 Eigenvalue and variance explained of principal component analysis

403

\begin{tabular}{cccc}
\hline Component & eigenvalue & $\begin{array}{c}\text { Variance } \\
\text { explained(\%) }\end{array}$ & $\begin{array}{c}\text { Cumulative } \\
\text { variance } \\
\text { explained(\%) }\end{array}$ \\
\hline 1 & 4.39 & 73.12 & 73.12 \\
2 & 1.15 & 19.17 & 92.29 \\
3 & 0.32 & 5.24 & 97.52 \\
4 & 0.13 & 2.09 & 99.62 \\
5 & 0.01 & 0.24 & 99.85 \\
6 & 0.01 & 0.15 & 100.00 \\
\hline
\end{tabular}

404 We hide the absolute value of the factor less than 0.5 and use the Varimax 405 method to rotate the original factor matrix. The rotating factor matrix shows that 
406 component 1 consists of five factors (NDWI, NDVI, MC, EMC, and WS) and 407 component 2 contains only BM factors (Table 5). Using the rotation factor matrix to 408 calculate the eigenvalue and variance explained percentage, components 1 and 2 show $4094.20,82 \%$ and $0.92,18 \%$, respectively, which can be considered as the effect of each 410 component on the vulnerability of wildfires. The larger the coefficient in the factor 411 matrix, the greater the weight it occupies in the component. Therefore, the factor load 412 in the component multiplied by the percentage of variance explained can be calculated 413 as a weight for the effect of each factor on the vulnerability of wildfires.

414 Table 5 Post-rotation factor matrix

\begin{tabular}{cccccc}
\hline & \multicolumn{2}{c}{$\begin{array}{c}\text { Post-rotation factor } \\
\text { matrix }\end{array}$} & \multicolumn{2}{c}{ Score factor matrix } \\
Factor & $\begin{array}{c}\text { Component } \\
\text { Component }\end{array}$ & $\begin{array}{c}\text { Component } \\
\text { Component }\end{array}$ & Weight(\%) \\
\hline niNDWI & 1 & 2 & 1 & 2 & 16.4 \\
nNDVI & -0.92 & & 0.20 & & 17.3 \\
niMC & 0.84 & & 0.21 & & 14.9 \\
nBM & & 0.96 & 0.18 & & 18.0 \\
niEMC & 0.94 & & 0.21 & 1 & 17.1 \\
nWS & 0.91 & & 0.20 & & 16.2 \\
Eigenvalue & 4.20 & 0.92 & - & - & - \\
\hline
\end{tabular}

416 4.1.5 Monthly wildfire nVulnerability

417 Monthly wildfire vulnerability is calculated based on the weight of the factors. 418 Analysis of potential wildfires shows that December is the most vulnerable, indicating 419 a period of dryness, fuel-rich and good wildfire conditions. Overall, there is a high 420 degree of vulnerability from October to the following April (nVulnerability $>0.5$ ), and 421 low vulnerability from May to September.

422 According to the fire department's 2006-2015 records, the largest number was 423 about 200 in March and the second-highest number of fires in October (Fig. 4). The 424 degree of vulnerability from November to the following February was slightly 425 different from the record of fire cases, while the trend of March to October was more 426 consistent with the record of fire cases. It can be seen that the month of high fire 427 vulnerability does not reflect the actual occurrence of fire records. 


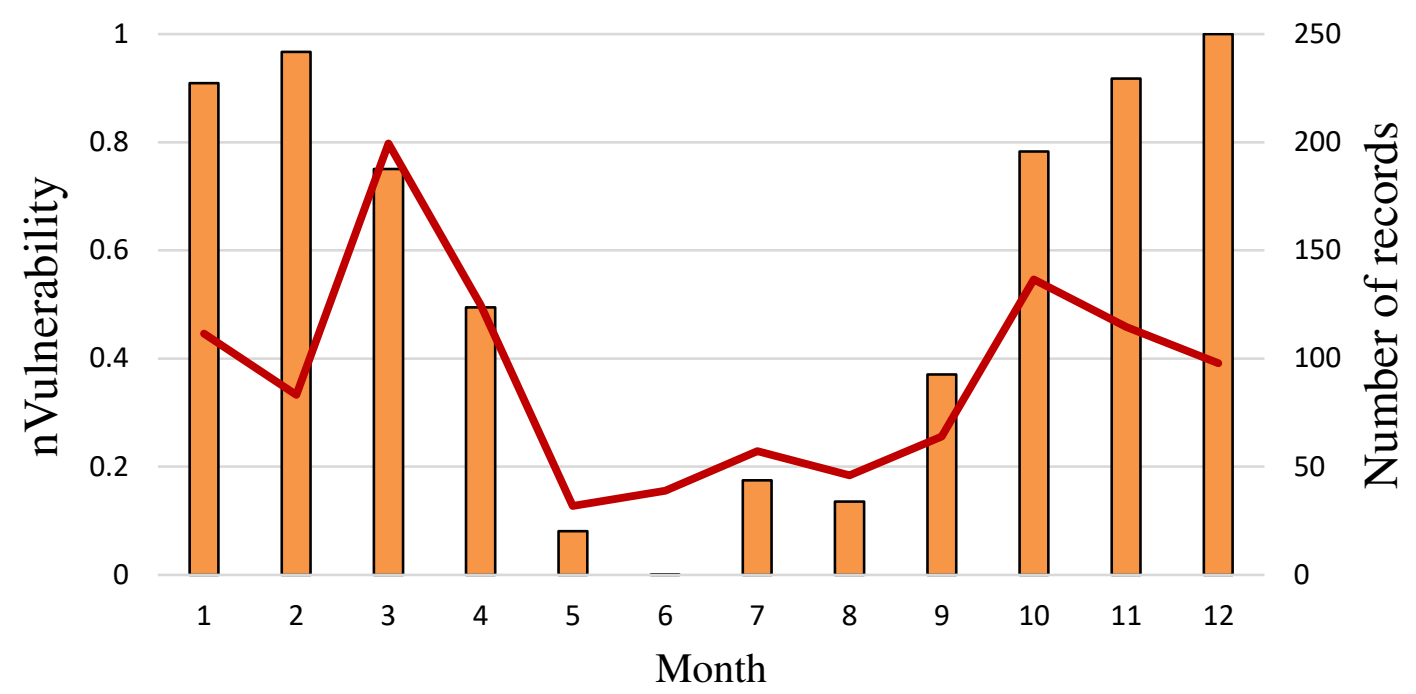

$\square$ nVulnerability $\longrightarrow$ Number of records

Fig. 4 Monthly changes in wildfire nVulnerability and fire case records.

Correlation of monthly wildfire nVulnerability and fire case is expressed as a 429 positive linear relationship, but overall can only explain $49 \%(p<0.05)$. Only 430 considering vulnerability factors alone is not sufficient to reflect wildfire risk. Fire 431 nVulnerability during the rainy season (May-September) and dry season 432 (October-April) was analyzed (Fig. 5). The monthly wildfire nVulnerability and fire 433 case records show highly positive correlation $\left(\mathrm{R}^{2}=0.77, p=0.05\right)$ during the rainy 434 season, while the dry season is negatively correlated $\left(\mathrm{R}^{2}=0.22, p=0.28\right)$. Wildfire 435 nVulnerability during the dry season can only explain the $22 \%$ wildfire risk, so it is 436 necessary to add the hazard to explore the risk of wildfires, especially during the dry 437 season. 


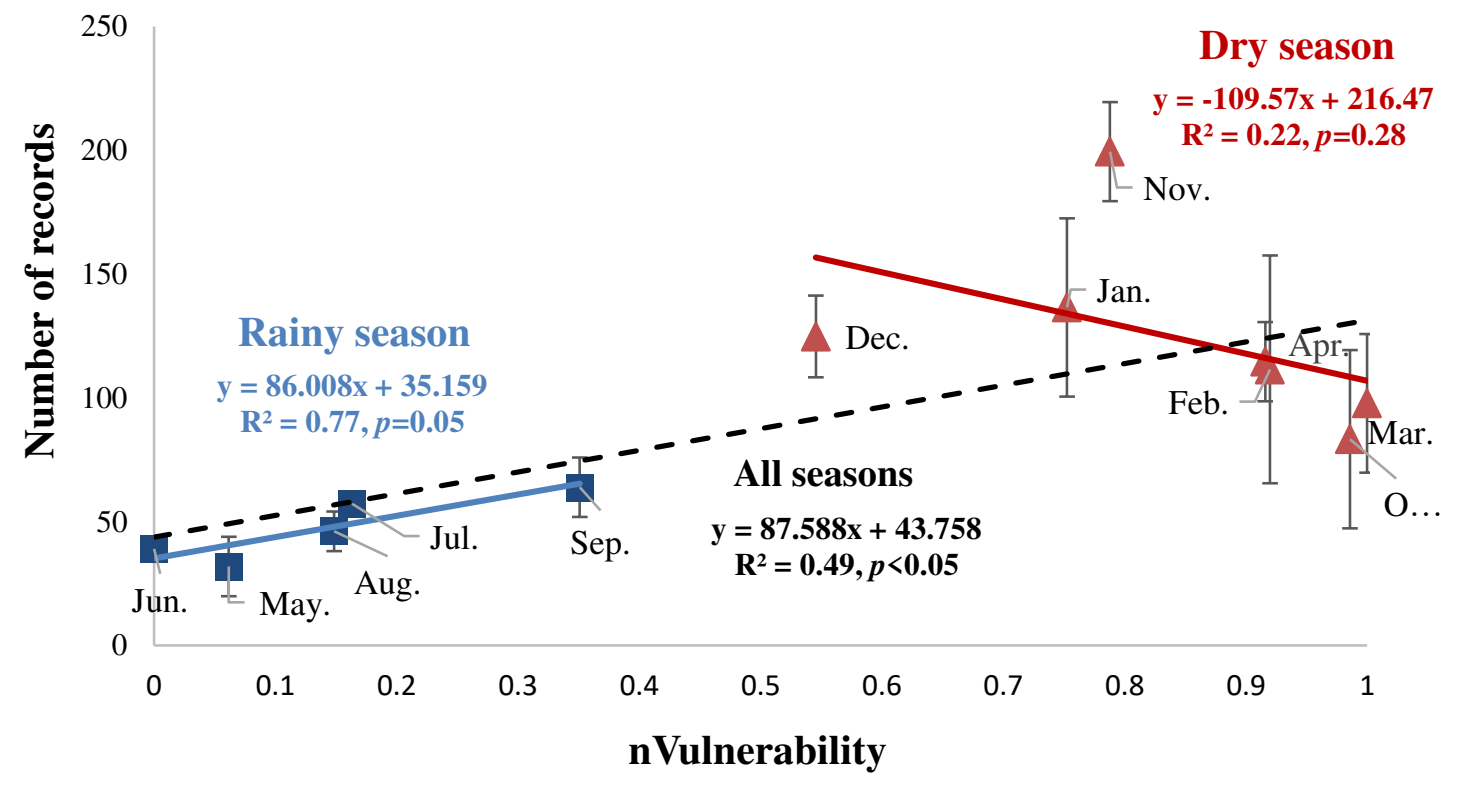

Fig. 5 The correlation between wildfire vulnerability and fire cases in each month from 2006 to 2015, with an average monthly explanation rate of $49 \%$; if divided into dry and rainy seasons, the explanation rate for the dry season is only $22 \%$.

\subsubsection{The initial threshold of $d N B R$}

The initial threshold of $d N B R$ can be obtained from the false color image of the 441 burned sites by the adjustment of the grid $d N B R$ value. The difference between the 442 average values of the $N B R$ of the two phases of remotely measured image samples 443 (Overall $d N B R$ ) is used as the degree of influence of the atmospheric humidity change 444 between the two phases of images. In each wildfire event, the initial threshold of $d N B R$ obtained by adjusting the grid $d N B R$ value was used as the y variable, and

446 Overall $d N B R$ was used as the $\mathrm{x}$ variable for regression analysis. The correlation of 447 the overall $d N B R$ and initial threshold of $d N B R$ shows a high correlation $\left(\mathrm{R}^{2}=0.78\right.$, $448 p<0.001$ ) (Fig. 6). Based on the change in atmospheric humidity between the two 449 periods, the initial threshold of $d N B R$ can be obtained through the application of regression, which is beneficial to accurately extract the burned area.

451 The overall $d N B R>0$ indicates that atmospheric humidity of pre-fire is wetter 452 than that of post-fire, and the initial threshold increases as the $d N B R$ is larger (the 453 threshold converges to between $0.25-0.30$ ). The overall $d N B R<0$ indicates 454 atmospheric humidity of pre-fire is drier than that of post-fire, and the initial threshold 455 can be converged below 0.15 . 


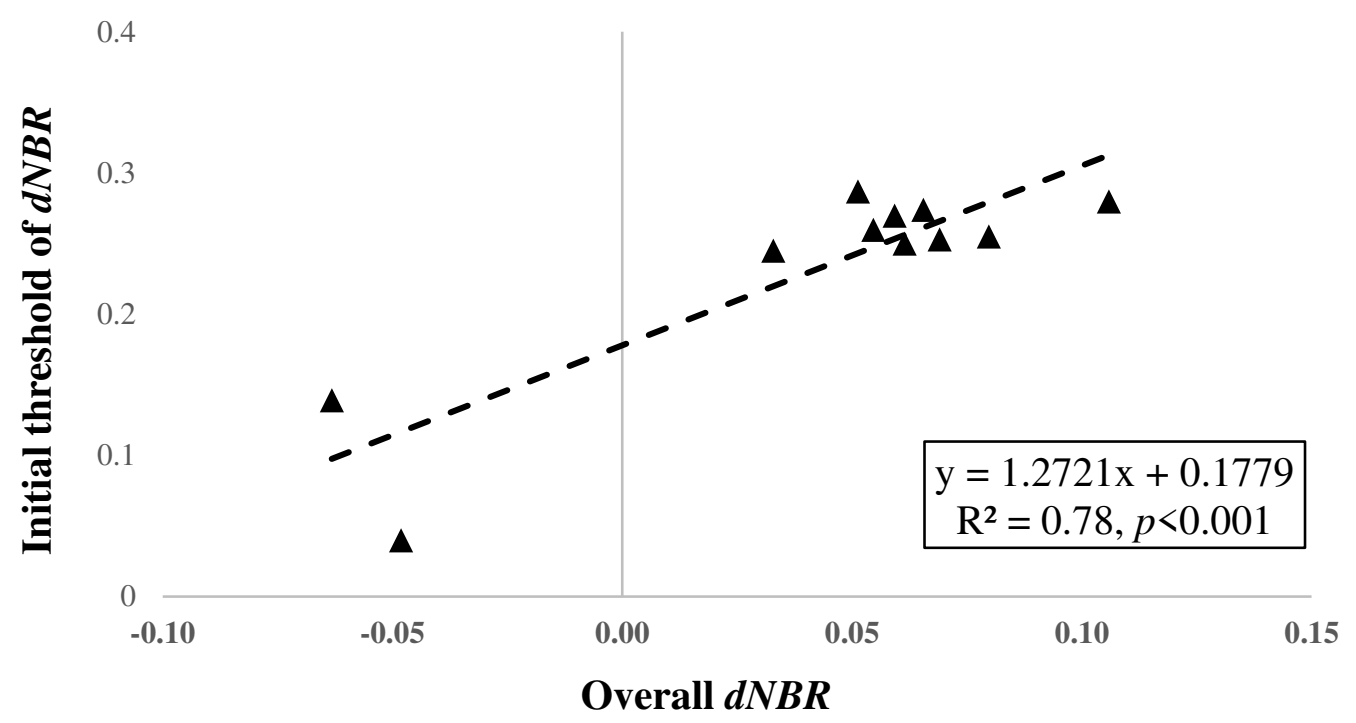

457

458 Fig. 6 The correlation between the overall $d N B R$ and the initial threshold of $d N B R .11$ 459

460

461

462

463

464

465

466

467

468

469

470

471

472

473

474

475

476

sets of $d N B R$ (22 telemetry images) are used to evaluate the influence of atmospheric humidity on the initial threshold of $d N B R$.

The monthly wildfire area for the 2006-2015 dry seasons (October-April) is calculated on the basis of the $d N B R$ threshold method described above, and the average area of the wildfire sits per period is standardized as a monthly risk index. Satellite image extraction is not possible for month-to-month analysis because it is affected by satellite trajectories and clouds. However, we have a long analysis year and provide a sufficient number of samples. The total area of wildfires is extracted from the interval between the selected images, during which the average area of the monthly wildfires is used as the area of the wildfires that occur each month during the dry season. The area ratio is calculated (compared to the maximum value of the average combustion area) and standardize the monthly hazard estimates (Table 6-7) to derive the risk value of the monthly wildfire using the risk model (vulnerability $\mathrm{x}$ hazard). The risk model is mainly used to correct the vulnerability of the dry season, while the level of risk during the rainy season is not considered, so the risk of the rainy season will not work. 


\begin{tabular}{|c|c|c|c|c|c|c|c|c|c|c|c|c|}
\hline Month & \multicolumn{3}{|c|}{ Number of samples } & \multicolumn{2}{|c|}{$\begin{array}{c}\text { Total area } \\
\text { of burn } \\
\text { site } \\
\left(\mathrm{m}^{2}\right)\end{array}$} & \multicolumn{2}{|c|}{$\begin{array}{l}\text { Average } \\
\text { burn area } \\
\qquad\left(m^{2}\right)\end{array}$} & Weight* & \multicolumn{2}{|c|}{$\begin{array}{c}\text { Normalized } \\
\text { weight }\end{array}$} & Hazard** & \\
\hline 10 & \multicolumn{3}{|c|}{5} & \multicolumn{2}{|c|}{$4,978,050$} & \multicolumn{2}{|c|}{995,610} & 0.88 & \multicolumn{2}{|c|}{0.67} & 1.67 & \\
\hline 11 & \multicolumn{3}{|c|}{5} & \multicolumn{2}{|c|}{$3,659,250$} & \multicolumn{2}{|c|}{731,850} & 0.65 & \multicolumn{2}{|c|}{0.00} & 1.00 & \\
\hline 12 & \multicolumn{3}{|c|}{5} & \multicolumn{2}{|c|}{$3,901,350$} & \multicolumn{2}{|c|}{780,270} & 0.69 & \multicolumn{2}{|c|}{0.12} & 1.12 & \\
\hline 1 & \multicolumn{3}{|c|}{3} & \multicolumn{2}{|c|}{$2,212,350$} & \multicolumn{2}{|c|}{737,450} & 0.66 & \multicolumn{2}{|c|}{0.01} & 1.01 & \\
\hline 2 & \multicolumn{3}{|c|}{3} & \multicolumn{2}{|c|}{$1,496,700$} & \multicolumn{2}{|c|}{748,350} & 0.67 & \multicolumn{2}{|c|}{0.04} & 1.04 & \\
\hline 3 & \multicolumn{3}{|c|}{2} & \multicolumn{2}{|c|}{$1,984,500$} & \multicolumn{2}{|c|}{992,250} & 0.88 & \multicolumn{2}{|c|}{0.66} & 1.66 & \\
\hline 4 & \multicolumn{3}{|c|}{1} & & 25,000 & \multicolumn{2}{|c|}{$1,125,000$} & 1.00 & \multicolumn{2}{|c|}{1.00} & 2.00 & \\
\hline $\begin{array}{l}478 \\
479 \\
480 \\
481 \\
482\end{array}$ & \multicolumn{12}{|c|}{$\begin{array}{l}\text { * Area ratio, compared with the maximum value of average burn area } \\
\text { ** Normalized weight plus } 1 \text { as the hazard to avoid subsequent risk analysis to } \\
\text { dilute vulnerability. }\end{array}$} \\
\hline Month & 1 & 2 & 3 & 4 & 5 & 6 & 7 & 8 & 9 & 10 & 11 & 12 \\
\hline Inerability & 0.92 & 0.99 & 0.79 & 0.55 & 0.06 & 0.00 & 0.16 & 0.15 & 0.35 & 0.75 & 0.92 & 1.00 \\
\hline Hazard & 1.01 & 1.04 & 1.66 & 2 & $1^{*}$ & $1^{*}$ & $1 *$ & $1^{*}$ & $1 *$ & 1.67 & 1 & 1.12 \\
\hline Risk & 0.93 & 1.03 & 1.31 & 1.10 & 0.06 & 0.00 & 0.16 & 0.15 & 0.35 & 1.26 & 0.92 & 1.12 \\
\hline Risk* & 0.71 & 0.78 & 1.00 & 0.84 & 0.05 & 0.00 & 0.12 & 0.11 & 0.27 & 0.96 & 0.70 & 0.86 \\
\hline $\begin{array}{l}\text { imber of } \\
\text { report }\end{array}$ & 111.50 & 83.30 & 199.44 & 124.8 & 31.89 & 39.00 & 57.20 & 46.10 & 63.90 & 136.50 & 114.60 & 97.78 \\
\hline
\end{tabular}

$483 *$ The minimum hazard of the dry season is used as hazard of the rainy season

484

485 After correcting the monthly risk value, the fire risk model is obtained, and the 486 result shows that the overall correlation has increased (Fig. 7) to a very significant 487 level, showing a positive correlation trend. Hazard has been added so that the 488 temporal distribution of the wildfire risk model can be verified. 


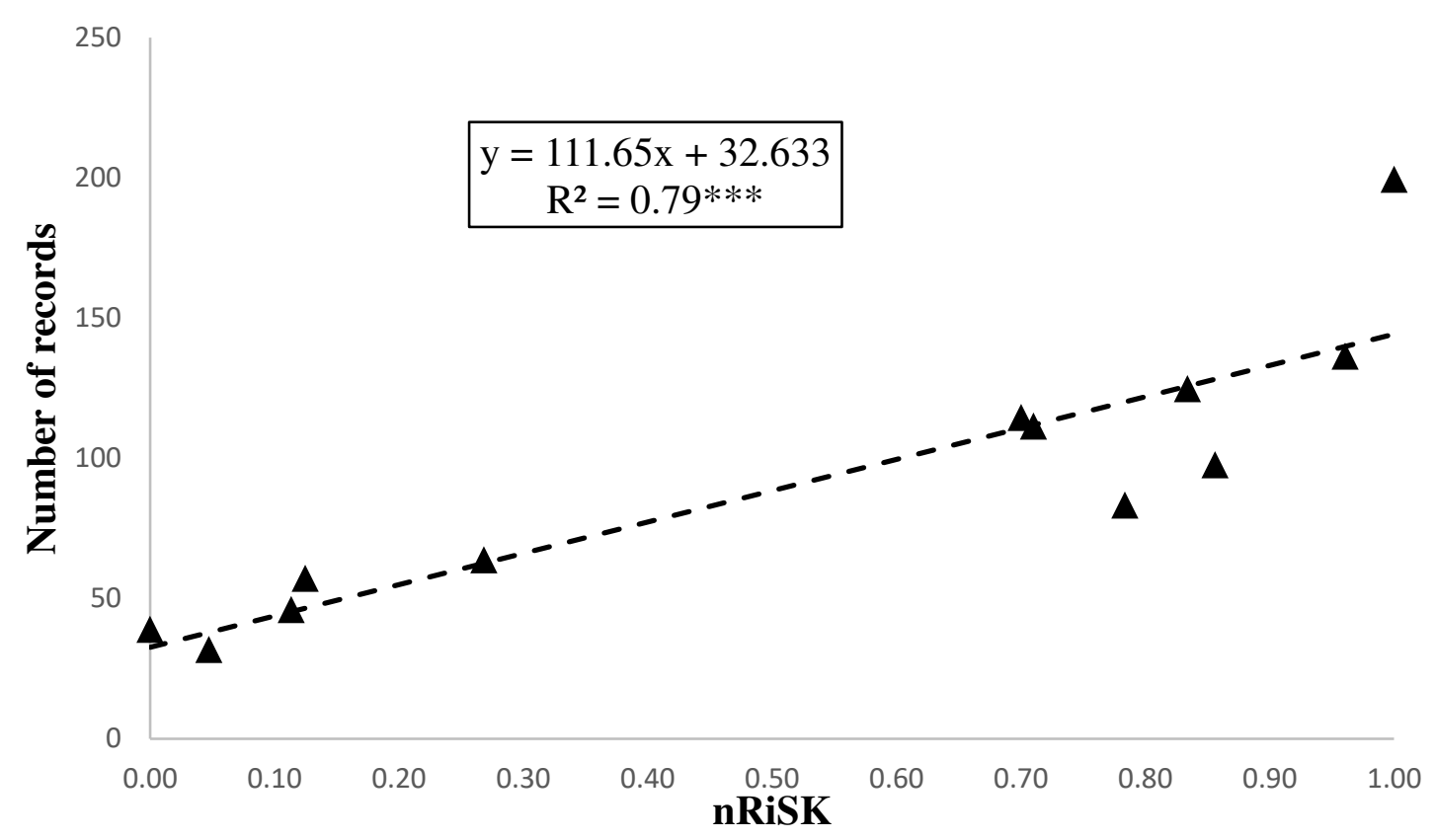

Fig. 7 Correlation of risk and number of records

4.2 Spatial distribution of wildfire risk

490

491

492

493

494

495

496

497

498

499

500

501

502

503

\subsubsection{Wildfire vulnerability}

According to the temporal distribution of wildfire risk, the peak of wildfires is at the beginning and end of the dry season. As a result, recent spatial environmental vulnerability information (2013-2015) has been used to simulate the spatial distribution of future wildfire hot spots. The spatial risk model is built with data of early dry season of 2013-2015 and maps of wildfire risk are delineated for reference in wildfire prevention. Therefore, NDVI and iNDWI were extracted from satellite images taken over three years in different years at the beginning of the dry season and standardized as factors reflecting biomass and plant moisture content.

Satellite image taken on October 16 and manual selection of training samples derived from Google Earth image of Nov. 23 (Fig. 8a), coupled with Maximum Likelihood Classification were used to estimate land cover types (Fig. 8b) of the most wildfire vulnerability in 2013, and the classification of fuel property can be derived as Fig. 8c. In order to evaluate the accuracy of land cover classification, the results of classification and real land cover were evaluated. 400 samples of land cover type were randomly to calculate accuracy analysis. The overall accuracy of image processing is $78 \%$ and the Kappa coefficient is 0.69 , indicating that the classification results are acceptable. 


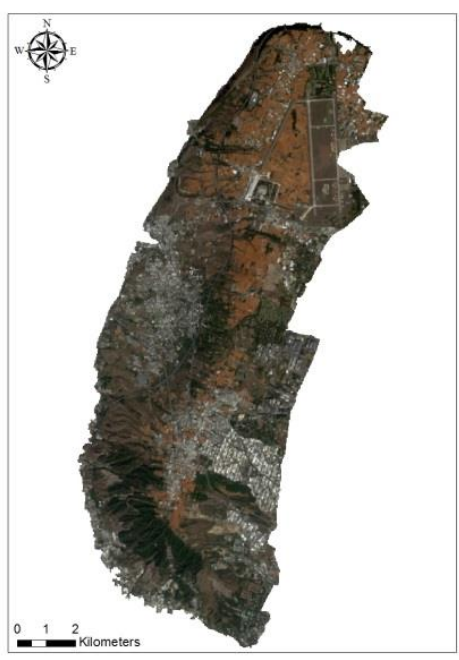

(a) Land cover status derived from Google Earth ${ }^{\circledR}$

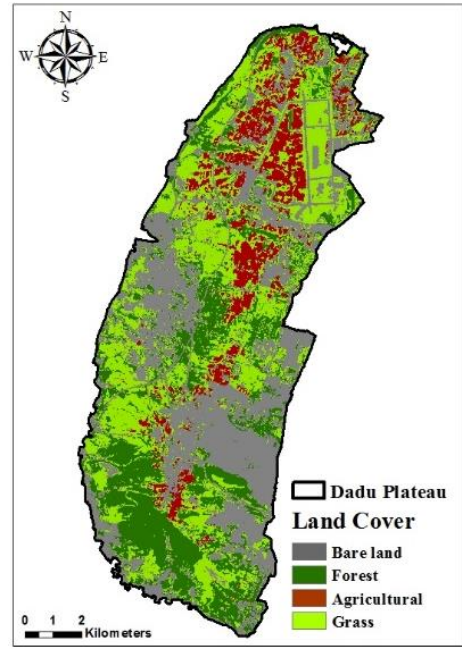

(b) Classification of land cover

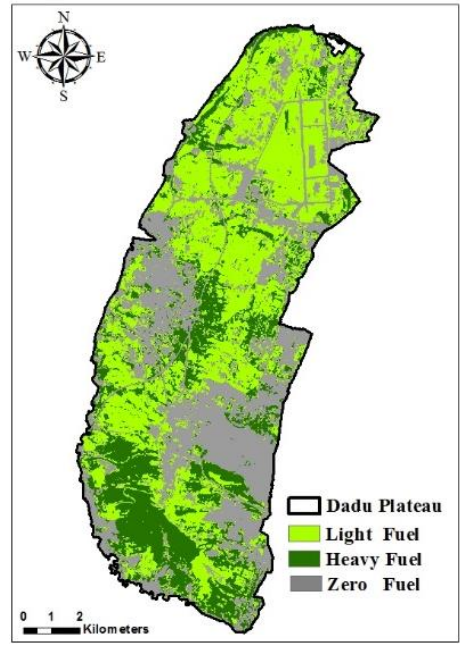

(c) Classification of fuel property

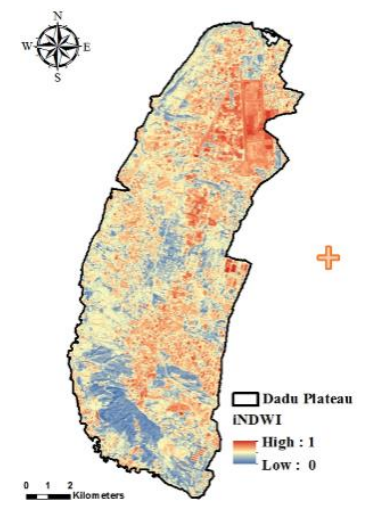

iNDWI

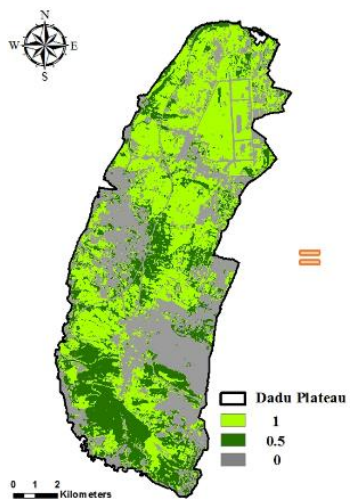

Fuel property

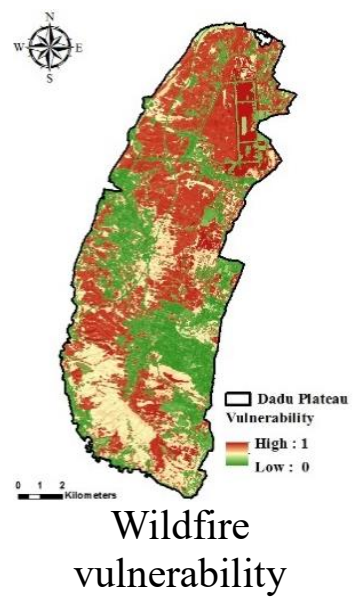

Fig. 9 Spatial distribution of wildfire vulnerability calculated by NDVI, iNDWI and fuel property

\subsubsection{Wildfire hazard}

Satellite images taken at the beginning of the high-risk period are used as pre-fire 
524 images, and post-fire images are taken at the end of the high-risk period. The spatial

525 distribution of burned sites during this period was extracted using the initial threshold

526 of $d N B R$. Fig. 10 shows that the initial threshold of $d N B R$ varies in different years.

527 The results of the $d N B R$ reflect low number of burned sites during 2014-2015 due to

528 dry season with sufficient rainfall. Five $d N B R$ maps were overlapped and standardized

529 to obtain a wildfire hazard index. A higher hazard index indicates that the region is 530 more likely to come into contact with fire sources and that wildfires occur more 531 frequently, which also means that the area is more affected by external forces (fire 532 sources).

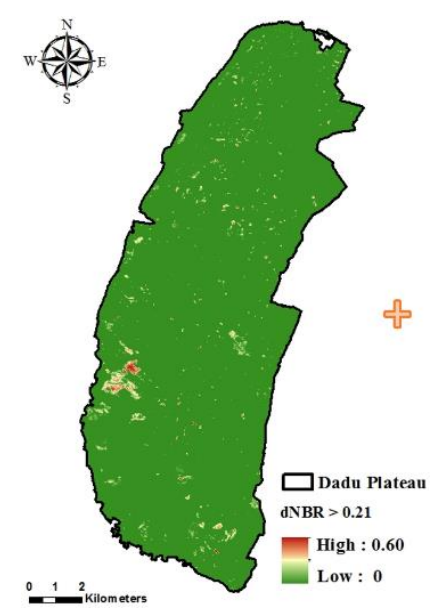

$2008 / 12 / 05-2009 / 04 / 12$

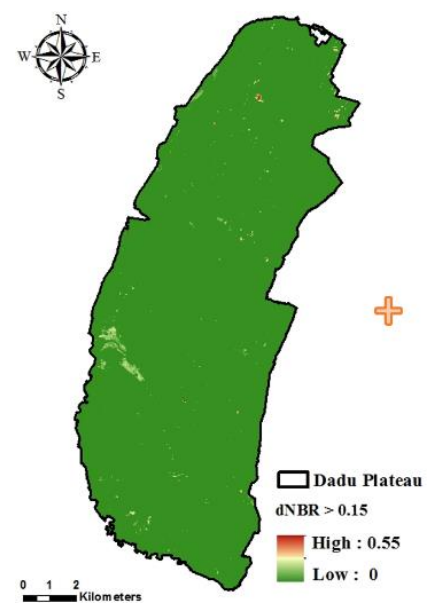

2013/11/17-2014/04/10

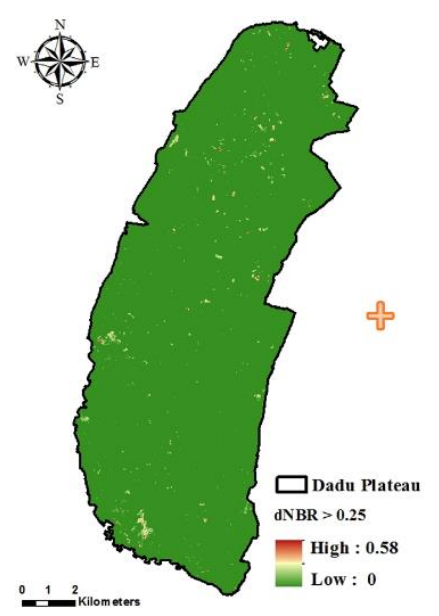

$2009 / 10 / 21-2010 / 02 / 26$

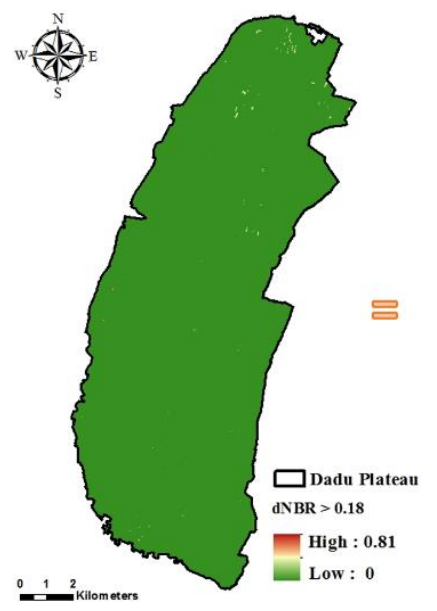

$2014 / 11 / 20-2015 / 03 / 28$

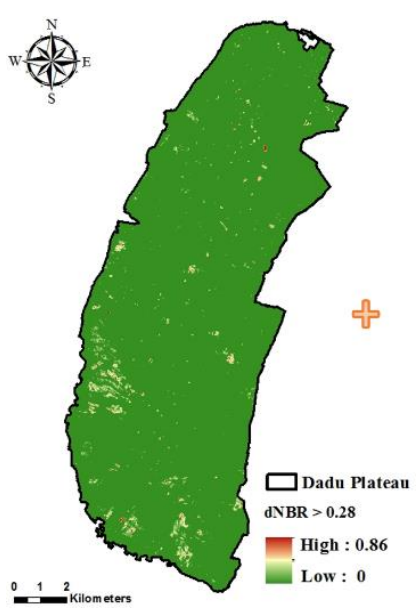

2010/11/09-2011/04/02

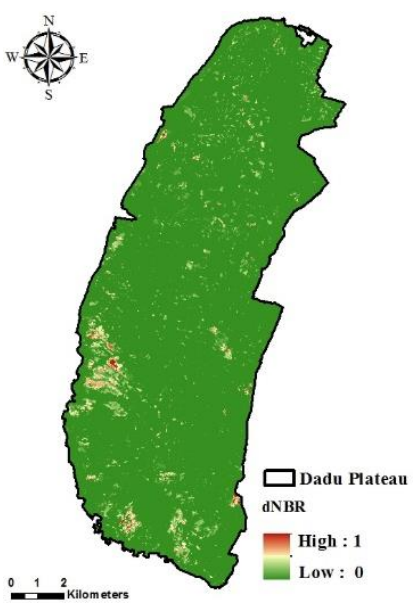

Wildfire hazard

Fig. 10 Wildfire hazard index calculated by analyzing the overlay of the annual burning sites

\subsubsection{Wildfire risk and model verification}

The spatial distribution of wildfire risk during the dry season in the Dadu Plateau 
539 can be obtained through the product of hazard and vulnerability (Fig. 11a). The NDVI 540 change matrix is used to determine the combustion areas of the dry season 541 (2008-2009, 2010-2011, and 2013-2014) for spatial model validation (Fig. 11b).

542 Using the village boundary map as a partition unit, the risk level of each village is 543 calculated as an independent variable, and the wildfire frequency of the partition unit 544 extracted from NDVI is used as a dependent variable. The results show that the risk of 545 wildfires is linear positively correlated (the determination coefficient increased to 0.78 , $546 \mathrm{p}<0.001$ ) with the frequency of wildfires (Fig. 12), which depicts that the spatial 547 wildfire risk model established in this study has high practical value.

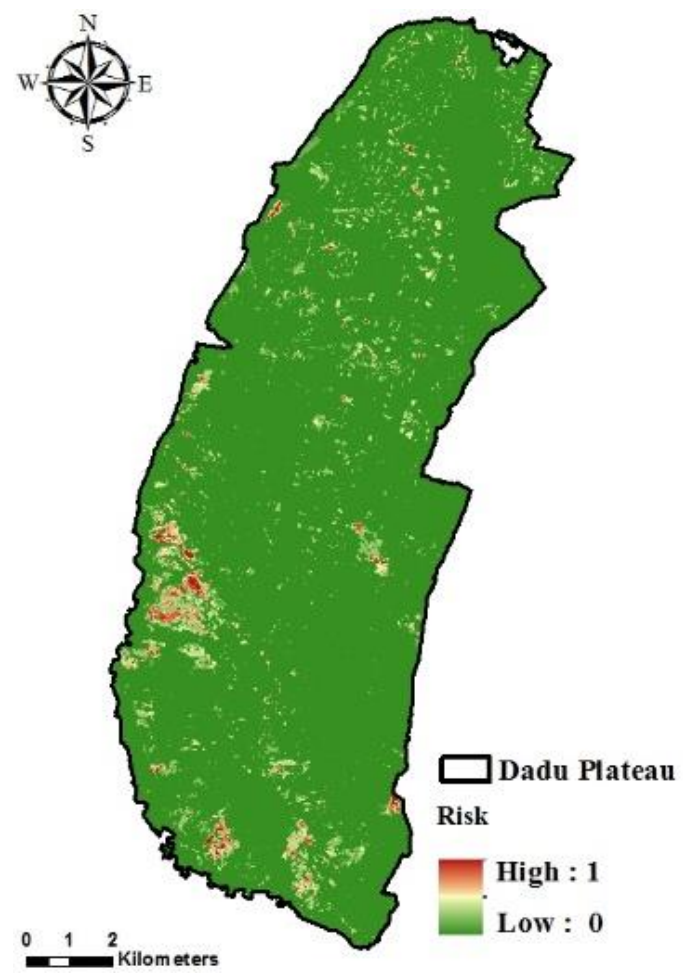

(a)Wildfire risk

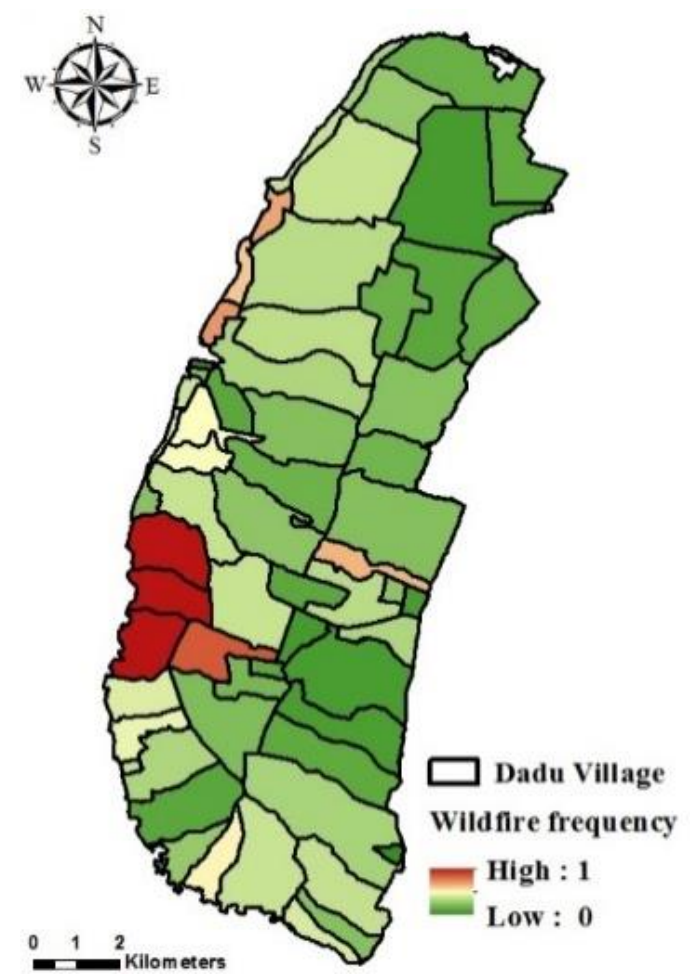

(b) Wildfire frequency, extracted from the NDVI change matrix

Fig. 11 Spatial distribution of wildfire risk and frequency. 


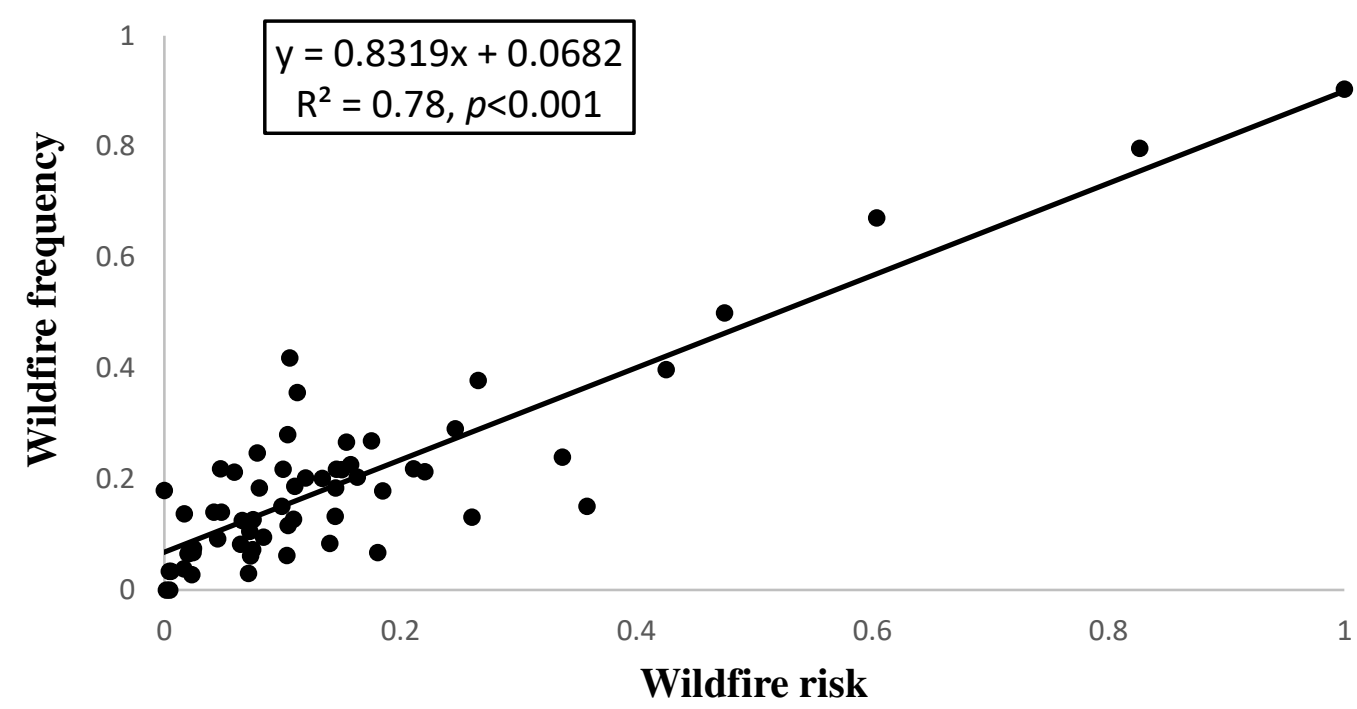

Fig. 12 The correlation of wildfire risk and wildfire frequency

\section{Discussions}

Disaster risk is defined as the probability of an event occurring under certain

551 circumstances. However, many studies use hazard, danger, or environmental

552 vulnerability as one or more indicators of wildfire risk (Oliveira et al., 2021; Parente

553 and Pereira, 2016; Silva et al., 2020), which may cause confusion to follow-up

554 researchers. The Canadian Forest Fire Risk Assessment System (CFFDRS) and the US

555 National Fire Risk Assessment System (NFDRS) both determine the wildfire hazard

556 levels based on fuel moisture and weather conditions, and regulate artificial fire

557 activities to reduce the risk of wildfires. This shows that the coupling relationship

558 between the dry flammable environment and the fire source can be regarded as a

559 wildfire risk. The study uses wildfire vulnerability to predict the hot spots of wildfire

560 disasters. Through field sampling observation and statistical analysis, the Dadu

561 Plateau grassland is rich in biomass throughout the year, and the moisture content of

562 plant tissue changes with the seasons, which affects the occurrence of wildfires.

563 Therefore, the environmental vulnerability analysis can only explain $49 \%$ of wildfires,

564 and the explanation rate in the dry season is even lower. Since wildfire risk is defined

565 as the hazard and vulnerability of the environment to fire sources, adding hazard

566 analysis helps to clearly explain the factors that affect the occurrence of wildfires, and

567 is of great significance to fire rescue.

568 Taiwan is located in the Asian monsoon climate zone. Summer is the rainy 
season, and the temperature is lower in autumn and winter in the dry season. This is different from the nature of wildfires that occur at the high temperature during the dry season in the western United States (Westerling et al. 2003, 2006; Williams et al. 2019). In the study area, moisture content is more important for wildfire frequency.

573 The monthly vulnerability and fire frequency indicate that drought and abundant fuel 574 are suitable environments for wildfires from October to April. However, 575 environmental vulnerability only accounts for $49 \%$ of monthly fire records. 576 According to the statistics of forest fires in various countries, the vast majority of 577 forest fires are caused by man-made fires (Soares and Batista, 2007), which is similar 578 to the cause of wildfires on the Dadu Plateau (Chuang 2015). By analyzing the 579 high-risk March (2013 to 2015) fire records (Fig. 4), the relationship between 580 wildfires and land use in the study area was discussed (Fig. 13). The wildfires around 581 the cemetery accounted for $68 \%$ of the total. The main reason is that March in Taiwan 582 is the Qingming Festival for ancestors and tomb sweeping. Activities such as weeding, 583 worshiping, and smoking in the cemetery inadvertently increase the chances of fire 584 and fuel contact, leading to frequent wildfires. However, it is not the environment 585 most prone to wildfires. This is mainly because human activities increase the risk of 586 wildfires, and it has been proven that only considering environmental vulnerability 587 does not reflect the actual situation of wildfires. This is similar to other Asian island 588 countries such as Japan and Vietnam. The former is due to religious festivals (A 589 Summery Festival of the Dead) (Zorn et al. 2001), while the latter is caused by 590 behaviors such as smoking bees in order to collect honey from bees (Le et al. 2014).

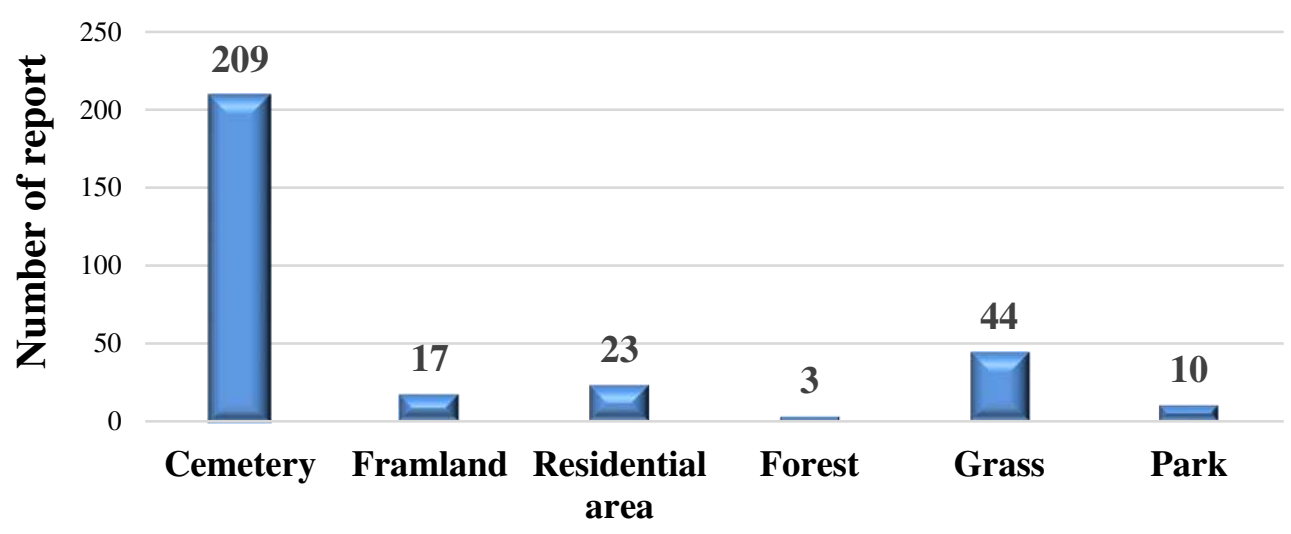

Fig. 13 Statistics of wildfire reports by different land use types from 2013 to March 2015 
Human factors are important for wildfire risk models, but the current Canadian

593 Forest Fire Hazard Assessment System (CFFDRS) and the US National Fire Hazard 594 Assessment System (NFDRS) do not explicitly include human factors (Silva et al. 595 2020). This may be related to the huge uncertainty and unpredictability of wildfires 596 caused by man-made fires. Population density, distance from roads, location and 597 number of historical fires are often used as human factors (González et al. 2018; Silva 598 et al. 2020). In countries where wildfires are frequent, historical wildfire events are 599 often used to assess potential wildfire risks (González et al. 2018).

600 The fire site can be considered as a potential wildfire location (hazard factor) due 601 to its high repeatability risk, and the vulnerability factor can be combined to assess the 602 wildfire risk. Since historical report records cannot determine the location of the fire, 603 this study extracts the $d N B R$ of the telemetry image to describe the location and 604 burning degree of the wildfire, and conducts fire hazard analysis. However, the use of $605 d N B R$ to extract wildfire sites is severely affected by atmospheric humidity. 606 Compared with forests, herbs are more affected by seasonal humidity changes (Birch 607 et al., 2015; Key and Benson, 2005; Miller and Thode, 2007). Therefore, the 608 traditional $d N B R$ extraction method needs to extract images from the same month 609 every other year to reduce the interference of environmental factors. Using satellite 610 images taken under different atmospheric humidity conditions, the relationship 611 between the initial threshold of $d N B R$ (grid $d N B R$ ) and the overall $d N B R$ can be 612 established to effectively extract wildfire locations. This research proposes an 613 innovative method that uses the correlation between the overall $d N B R$ and the initial 614 threshold of $d N B R$ to eliminate the defects of the traditional fixed threshold. This 615 method can effectively extract wildfire relics in a short time, which is beneficial to the 616 study of periodic wildfire areas.

617 As the study area is surrounded by important metropolitan areas, the long-term 618 periodic burning of the Dadu Plateau has severely reduced the forest area. After a 619 wildfire, guinea grass may grow quickly and hinder the succession of other plants (Fig. 620 14). Ecologically, migratory birds are affected by the decline in species richness and 621 loss of forest ecological habitat (Tsai 2005). Large numbers of grassland are subject to 622 periodic wildfire, which may reduce water storage capacity of the study area and 623 easily lead to flooding in the lower urban area during heavy rains (Cho 2017). 


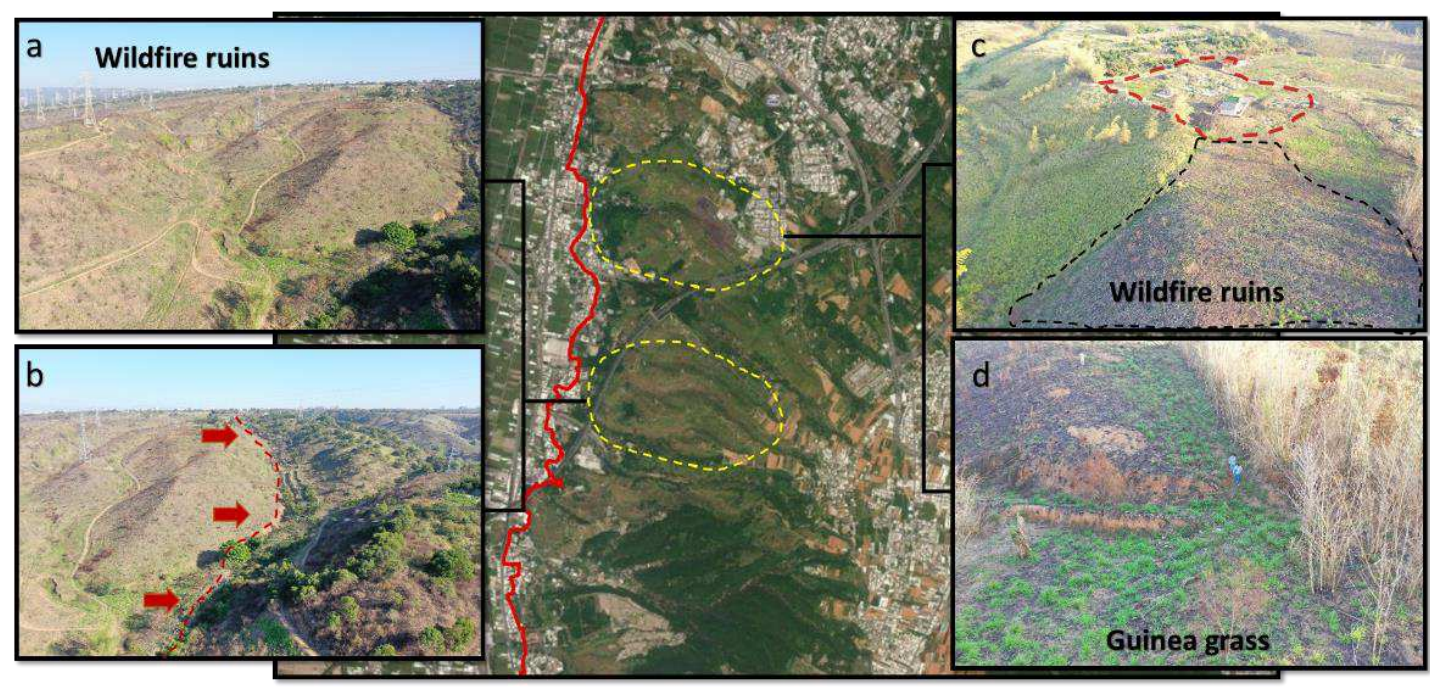

Fig. 14 Scene photos of areas with high fire risk (a: mosaic landscape, b: obvious interlaced zone, c: delayed plant succession, d: wildfire-adapted vegetation germinates one week later)

In the case of periodic wildfires, fuel is not easy to accumulate, and wildfires are

627 generally not too large and can be extinguished quickly; however, society must bear 628 the damage of fires, and the local ecological and natural landscape system is gradually 629 changing. Considering spatial wildfire risk management, it is recommended to 630 introduce the concept of fire belts in densely populated sample areas, and to use 631 village boundaries as the zoning unit for wildfire prevention. The village boundary 632 map is used as the zoning unit, the risk level of each village is calculated as a separate 633 variable, and the wildfire frequency of the zoning unit extracted from NDVI is used as 634 the dependent variable. The results show that the spatial wildfire risk model 635 established in this study has high practical value. The risk value of wildfires in each 636 village is divided into five levels (Fig. 15); it can be graded according to the risk value 637 of wildfires in each village, which can provide reference and application for related 638 departments in zoning management and disaster relief manpower layout. 


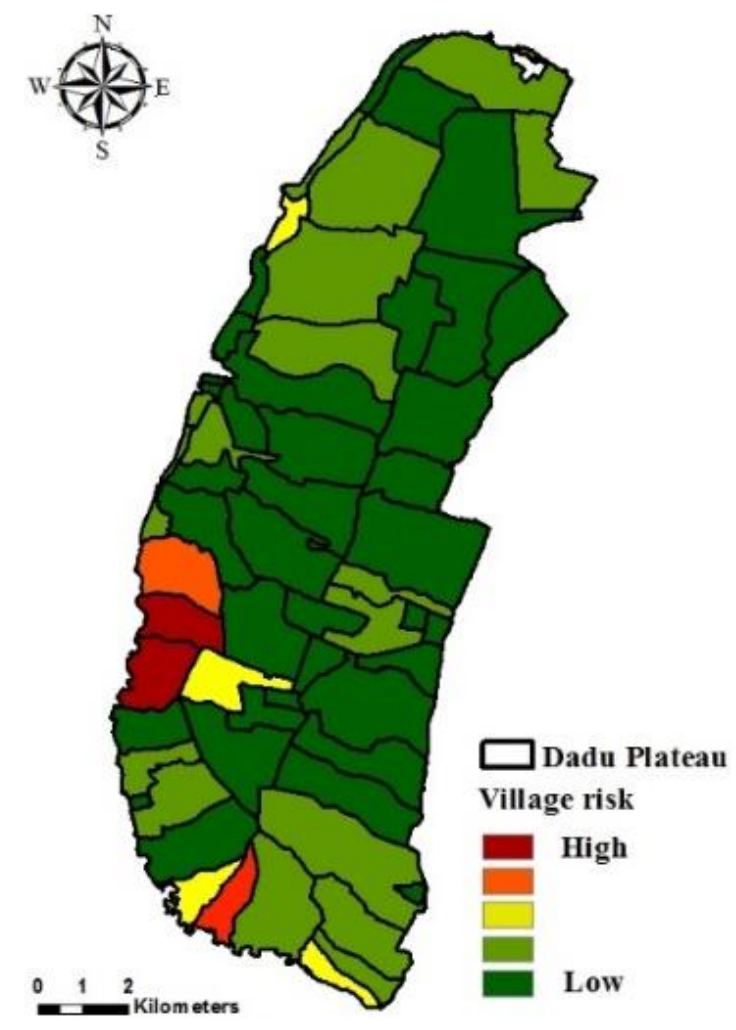

Figure 15 Risk levels of wildfires in each village

640

\section{5. Conclusion}

642 As fire behavior involves complex environmental issues, this study uses 643 environmental indicators combined with risk analysis to explore the temporal and 644 spatial distribution of fire hotspots. In areas with periodic wildfires, if only the 645 vulnerability of wildfires is considered, the frequency of wildfires cannot be explained; 646 this shows the importance of wildfire hazards. Therefore, in addition to environmental 647 vulnerability, man-made fire hazards play an important role in the management of 648 periodic fire areas. In the field of wildfire prevention and management, attention 649 should be paid to the cooperative relationship between stakeholders. The 650 establishment of village-level fire risk maps can enable stakeholders to improve their 651 fire drill skills, guide them to form a consensus on wildfire risk and management, 652 implement actual fire safety actions, and gradually improve and reduce the damage 653 caused by periodic fires to the environmental landscape. 


\section{Data availability statement}

656 Meteorological data is extracted from the annual weather report of the central 657 weather bureau (https://e-service.cwb.gov.tw/HistoryDataQuery/). Satellite images are 658 derived from the center of the US Geological Survey website 659 (http://earthexplorer.USGS.gov/). Fire case provided by the Fire bureau 660 (https://www.fire.taichung.gov.tw/home.asp).

\section{Conflicts of interest}

662 The authors declare no conflicts of interest.

\section{Acknowledgements}

664 This research was supported by grants from the Ministry of Science and 665 Technology of Taiwan R.O.C. (104-2313-B-005-030 and 105-2621-M-005-002-MY3).

\section{Reference}

667 Abatzoglou JT, Williams AP, Boschetti L, et al (2018) Global patterns of interannual 668

$$
\text { relationships. }
$$

Glob

Chang

Biol 24:5164-5175. https://doi.org/10.1111/GCB.14405

Ascoli D, Russo L, Giannino F, et al (2018) Firebreak and Fuelbreak. Encycl Wildfires Wildland-Urban Interface

Fires

$1-9$. https://doi.org/10.1007/978-3-319-51727-8_70-1

Benda L, Dunne T (1997) Stochastic forcing of sediment supply to channel networks from landsliding and debris flow. Water Resour Res 33:2849-2863. https://doi.org/10.1029/97WR02388

Birch DS, Morgan P, Kolden CA, et al (2015) Vegetation, topography and daily weather influenced burn severity in central Idaho and western Montana forests. Ecosphere 6:. https://doi.org/10.1890/ES14-00213.1

Bowker MA, Belnap J, Rosentreter R, Graham B (2004) Wildfire-resistant biological soil crusts and fire-induced loss of soil stability in Palouse prairies, USA. Appl Soil Ecol 26:41-52. https://doi.org/10.1016/J.APSOIL.2003.10.005

Bowman DMJS, Balch JK, Artaxo P, et al (2009) Fire in the Earth System. Science (80- ) 324:481-484. https://doi.org/10.1126/SCIENCE.1163886

Brown AA, Davis KP (1973) Forest fire: control and use, 2d ed. McGraw-Hill Book Company, New York 
Caselles V, López García MJ (1991) Mapping burns and natural reforestation using thematic mapper data. Geocarto Int 6:31-37. https://doi.org/10.1080/10106049109354290

Chen A, Tang R, Mao J, et al (2020) Spatiotemporal dynamics of ecosystem fires and biomass burning-induced carbon emissions in China over the past two decades. Geogr Sustain 1:47-58. https://doi.org/10.1016/J.GEOSUS.2020.03.002

Chiu CR, Hsueh IC, Liu YA, Lai YJ (2012) Trend analysis of land-use and land-cover changes in Dadu Hill, Taichung. Urban Plan 39:25-50. https://doi.org/10.6128/CP.39.1.25

Chiu CR, Tseng JC, Huang WD, Yang CM (2004) Grey Relational Analysis of the Effect of Climate Factors on the Satellite Remote Sensing Brightness Index (BRI) of Guinea grass in Mt. Dadu Area. Crop Environ Bioinforma 1:207-214. https://doi.org/10.30061/CEB.200409.0006

Cho CC (2017) Water conservation hotspots selection at the Dadu Plateau by using index of land cover changes. J Soil Water Conserv 49:1963-1978

Chuang YL (2015) Application of fire risk analysis for wildfire management at Dadu terrace. National Chung Hsing University

Costa JE (1987) A comparison of the largest rainfall-runoff floods in the United States with those of the People's Republic of China and the world. J Hydrol 96:101-115. https://doi.org/10.1016/0022-1694(87)90146-6

Cui X, Alam MA, Perry GL, et al (2019) Green firebreaks as a management tool for wildfires: Lessons from China. J Environ Manage 233:329-336. https://doi.org/10.1016/J.JENVMAN.2018.12.043

Epting J, Verbyla D, Sorbel B (2005) Evaluation of remotely sensed indices for assessing burn severity in interior Alaska using Landsat TM and ETM+. Remote Sens Environ 96:328-339. https://doi.org/10.1016/J.RSE.2005.03.002

Fang L, Yang J (2014) Atmospheric effects on the performance and threshold extrapolation of multi-temporal Landsat derived dNBR for burn severity assessment. Int J Appl Earth Obs Geoinf 33:10-20. https://doi.org/10.1016/J.JAG.2014.04.017

Fernández P, Rodríguez A, Gutiérrez D, et al (2019) Firebreaks as a barrier to movement: the case of a butterfly in a Mediterranean landscape. J Insect Conserv 2019235 23:843-856. https://doi.org/10.1007/S10841-019-00175-5

Fiorucci P, Gaetani F (2007) Dynamic fire danger mapping from satellite imagery and 
meteorological forecast data. Earth Interact 11:1-17. https://doi.org/10.1175/EI199.1

González C, Castillo M, García-Chevesich P, Barrios J (2018) Dempster-Shafer theory of evidence: A new approach to spatially model wildfire risk potential in central Chile. Sci Total Environ 613-614:1024-1030. https://doi.org/10.1016/j.scitotenv.2017.09.105

Gudmundsson L, Rego FC, Rocha M, Seneviratne SI (2014) Predicting above normal wildfire activity in southern Europe as a function of meteorological drought. Environ Res Lett 9:084008. https://doi.org/10.1088/1748-9326/9/8/084008

Hall RJ, Freeburn JT, DeGroot WJ, et al (2008) Remote sensing of burn severity: Experience from western Canada boreal fires. Int J Wildl Fire 17:476-489. https://doi.org/10.1071/WF08013

Hasan MM, Burian SJ, Barber ME (2020) Determining The Impacts of Wildfires on Peak Flood Flows in High Mountain Watersheds. Int J Environ Impacts Manag Mitig Recover 3:339-351. https://doi.org/10.2495/EI-V3-N4-339-351

Holland SM (2019) principal components analysis (PCA). Department of Geology, University of Georgia, Athens, GA 30602-2501, 2455 Teller Road, Thousand Oaks, California 91320

Hsiao CW (2003) The Study on Estimating temporal-spatial distribution of Forest Fire Danger Rating in Taiwan. National Taiwan University

Intergovernmental Panel on Climate Change (2014) Fifth Assessment Report(AR5). Intergov Panel Clim Chang

Jackson M, Roering JJ (2009) Post-fire geomorphic response in steep, forested landscapes: Oregon Coast Range, USA. Quat Sci Rev 28:1131-1146. https://doi.org/10.1016/j.quascirev.2008.05.003

Jolliffe IT, Cadima J (2016) Principal component analysis: a review and recent developments. Philos Trans R Soc A Math Phys Eng Sci 374:. https://doi.org/10.1098/RSTA.2015.0202

Jolly WM, Cochrane MA, Freeborn PH, et al (2015) Climate-induced variations in global wildfire danger from 1979 to 2013. Nat Commun 6: https://doi.org/10.1038/ncomms8537

Karamihalaki M, Stagakis S, Sykioti O, et al (2016) Monitoring drought effects on mediteranean conifer forests using spot-vegetation NDVI and NDWI timeseries. Eur Sp Agency, Spec Publ 740:188-192 
Key CH, Benson NC (2005) Landscape assessment: Ground measure of severity; the Composite Burn Index, and remote sensing of severity, the Normalized Burn Index. In: General Technical Report RMRS. USDA Forest Service, Rocky Mountain Research Station, Ogden, UT, pp 1-51

Lai YJ (2003) The study on estimating temporal-spatial distribution of solar irradiance in watershed. National Taiwan University

Lasaponara R (2005) Inter-comparison of AVHRR-based fire susceptibility indicators for the Mediterranean ecosystems of southern Italy. Int J Remote Sens 26:853870. https://doi.org/10.1080/0143116042000274131

Laschi A, Foderi C, Fabiano F, Neri F (2019) Forest Road Planning, Construction and Maintenance to Improve Forest Fire Fighting: a Review. Croat J For Eng 40:207219

Le TH, Nguyen TNT, Lasko K, et al (2014) Vegetation fires and air pollution in Vietnam. Environ Pollut

195:267-275. https://doi.org/10.1016/j.envpol.2014.07.023

Lee CY (2013) Changes in Soil Nutrients, Arbuscular Mycorrhizal Fungi and Invasive Plant Growth under Repeated Fire at Dadu Tableland, Central Taiwan. National Taiwan University

Li B (1990) Natural resources and environment of Ordos plateau inInner Mongolia (In Chinese). Sciences Press, Beijing

Lillesand T, Kiefer RW, Chipman JW (2000) Remote Sensing and Image Interpretation: John Wiley \& Sons Inc, New York

Lin CC, Chiu CR, Chen MY, et al (2005) Modeling Fire Danger Prediction of Dadu Mountain Area. Q J Chinese For 38:83-94. https://doi.org/10.30064/QJCF.200503.0006

Lin JK, Yang KC (2001) Wildfire on the Dadu Terrace. In: Environ. Inf. Cent. https://e-info.org.tw/node/12089. Accessed 14Sep2021

Lin MD, Rau JY, Tseng HH, et al (2008) Characterizing PAH emission concentrations in ambient air during a large-scale joss paper open-burning event. J Hazard Mater 156:223-229. https://doi.org/10.1016/J.JHAZMAT.2007.12.015

Lin SH (2000) Character and application of soil-conserving grasses. Weed Sci Bull 21:51-58. https://doi.org/10.6274/WSSROC-2000-021(1)-051

Lin SH (2013) Vegetation Engineering of Slopeland. Wu-Nan Book Inc.

Miller JD, Thode AE (2007) Quantifying burn severity in a heterogeneous landscape 

Environ 109:undefined-80. https://doi.org/10.1016/j.rse.2006.12.006

Moody JA, Shakesby RA, Robichaud PR, et al (2013) Current research issues related to post-wildfire runoff and erosion processes. Earth-Science Rev 122:10-37. https://doi.org/10.1016/j.earscirev.2013.03.004

Neary DG, Gottfried G. (2002) Fires and floods: post-fire watershed responses. Millpress Science Publishers, Rotterdam, The Netherlands

Oliveira S, Gonçalves A, Zêzere JL (2021a) Reassessing wildfire susceptibility and hazard for mainland Portugal. Sci Total Environ 762:143121. https://doi.org/10.1016/J.SCITOTENV.2020.143121

Oliveira S, Rocha J, Sá A (2021b) Wildfire risk modeling. Curr Opin Environ Sci Heal 23:100274. https://doi.org/10.1016/J.COESH.2021.100274

Parente J, Pereira MG (2016) Structural fire risk: The case of Portugal. Sci Total Environ 573:883-893. https://doi.org/10.1016/j.scitotenv.2016.08.164

Pausas JG, Llovet J, Rodrigo A, Vallejo R (2008) Are wildfires a disaster in the Mediterranean basin? A review. Int J Wildl Fire 17:713-723. https://doi.org/10.1071/WF07151

Pyne SJ, Andrews PL (1984) Introduction to Wildland Fire: Fire Management in the United States. John Wiley \& Sons Inc, New York

Ravi S, D’Odorico P, Wang L, et al (2009) Post-fire resource redistribution in desert grasslands: A possible negative feedback on land degradation. Ecosystems 12:434-444. https://doi.org/10.1007/s10021-009-9233-9

Rouse JW, Hass RH, Schel 1JA, Deering DW (1973) Monitoring vegetation systems in the Great Plains with ERTS

Sankey JB, Wallace CSA, Ravi S (2013) Phenology-based, remote sensing of post-burn disturbance windows in rangelands. Ecol Indic 30:35-44. https://doi.org/10.1016/j.ecolind.2013.02.004

Shakesby RA, Doerr SH (2006) Wildfire as a hydrological and geomorphological agent. Earth-Science Rev 74:269-307. https://doi.org/10.1016/j.earscirev.2005.10.006

Shyu TH, Lee YH, Tsou TP, Chiang MY (2003) Comparative Responses of Nine Weeds to Ozone Fumigation. 24:75-87

Silva IDB, Valle ME, Barros LC, Meyer JFCA (2020) A wildfire warning system applied to the state of Acre in the Brazilian Amazon. Appl Soft Comput J 89:. 
Soares RV, Batista AC (2007) Incêndios florestais controle, efeitos e uso do fogo. Universidade Federal do Paraná

Soverel NO, Coops NC, Perrakis DDB, et al (2011) The transferability of a dNBR-derived model to predict burn severity across 10 wildland fires in western Canada. Int J Wildl Fire 20:518-531. https://doi.org/10.1071/WF10081

Tian X, Zhao F, Shu L, Wang M (2013) Distribution characteristics and the influence factors of forest fires in China. For Ecol Manage 310:460-467. https://doi.org/10.1016/J.FORECO.2013.08.025

Tsai JH (2005) The relationship between the distribution of plant community and environment factor in the belt plot in Jhukeng-beikeng of Dadu Terrace, Taichung: a four-years study. Providence University

Turco M, Rosa-Cánovas JJ, Bedia J, et al (2018) Exacerbated fires in Mediterranean Europe due to anthropogenic warming projected with non-stationary climate-fire $\begin{array}{llllll}\text { models. } & \text { Nat } & \text { Commun } & 2018 & 91 & 9: 1-9 .\end{array}$ https://doi.org/10.1038/s41467-018-06358-z

Westerling AL, Gershunov A, Brown TJ, et al (2003) Climate and wildfire in the western United States. Bull Am Meteorol Soc 84:595-604. https://doi.org/10.1175/BAMS-84-5-595

Westerling AL, Hidalgo HG, Cayan DR, Swetnam TW (2006) Warming and earlier spring increase Western U.S. forest wildfire activity. Science (80- ) 313:940-943. https://doi.org/10.1126/science.1128834

Whitman E, Parisien M, Thompson DK, Flannigan MD (2018) Topoedaphic and Forest Controls on Post-Fire Vegetation Assemblies Are Modified by Fire History and Burn Severity in the Northwestern Canadian Boreal Forest. For 2018, Vol 9, Page 151 9:151. https://doi.org/10.3390/F9030151

Williams AP, Abatzoglou JT, Gershunov A, et al (2019) Observed Impacts of Anthropogenic Climate Change on Wildfire in California. Earth's Futur 7:892910. https://doi.org/10.1029/2019EF001210

Yamane T (1967) Statistics: An Introductory Analysis, 2nd Ed., New York: Harper and Row. New York : Harper and Row.

Yen TM, Wu YW (2004) Intergovernmental Panel on Climate Change. Q J For Res 26:47-60

Ying L, Cheng H, Shen Z, et al (2021) Relative humidity and agricultural activities 
856 dominate wildfire ignitions in Yunnan, Southwest China: Patterns, thresholds, and

857 implications. $\quad$ Agric $\quad$ For

Meteorol

307:108540.

858 https://doi.org/10.1016/J.AGRFORMET.2021.108540

859 Zorn T, Nakayama K, Hashiramoto O (2001) GLOBAL FOREST FIRE 860 ASSESSMENT 1990-2000 - FRA WP 55

861 